\title{
Current Advances in Plant Growth Promoting Bacteria Alleviating Salt Stress for Sustainable Agriculture
}

\author{
Slimane Mokrani ${ }^{1,2}$, El-hafid Nabti ${ }^{2, *}$ and Cristina Cruz ${ }^{3}$ \\ 1 Department of Agronomy, Laboratory of Research on Biological Systems and Geomantic (L.R.S.B.G.), \\ University of Mustapha Stambouli, P.O. Box 305, Mascara 29000, Algeria; distillateur@yahoo.com \\ 2 Laboratoire de Maitrise des Energies Renouvelables, Faculté des Sciences de la Nature et de la Vie, \\ Université de Bejaia, Bejaia 06000, Algeria \\ 3 CE3C - Centre for Ecology, Evolution and Environmental Changes Faculdade de Ciências da Universidade \\ de Lisboa, Edifício C2, Piso 5, Sala 2.5.03 Campo Grande, 1749-016 Lisboa, Portugal; ccruz@fc.ul.pt \\ * Correspondence: nabtielhafid1977@yahoo.com; Tel.: +00213-557794764
}

Received: 30 August 2020; Accepted: 23 September 2020; Published: 10 October 2020

\begin{abstract}
Humanity in the modern world is confronted with diverse problems at several levels. The environmental concern is probably the most important as it threatens different ecosystems, food, and farming as well as humans, animals, and plants. More specifically, salinization of agricultural soils is a global concern because of on one side, the permanent increase of the areas affected, and on the other side, the disastrous damage caused to various plants affecting hugely crop productivity and yields. Currently, great attention is directed towards the use of Plant Growth Promoting Bacteria (PGPB). This alternative method, which is healthy, safe, and ecological, seems to be very promising in terms of simultaneous salinity alleviation and improving crop productivity. This review attempts to deal with different aspects of the current advances concerning the use of PGPBs for saline stress alleviation. The objective is to explain, discuss, and present the current progress in this area of research. We firstly discuss the implication of PGPB on soil desalinization. We present the impacts of salinity on crops. We look for the different salinity origin and its impacts on plants. We discuss the impacts of salinity on soil. Then, we review various recent progress of hemophilic PGPB for sustainable agriculture. We categorize the mechanisms of PGPB toward salinity tolerance. We discuss the use of PGPB inoculants under salinity that can reduce chemical fertilization. Finally, we present some possible directions for future investigation. It seems that PGPBs use for saline stress alleviation gain more importance, investigations, and applications. Regarding the complexity of the mechanisms implicated in this domain, various aspects remain to be elucidated.
\end{abstract}

Keywords: alleviation; mechanisms; PGPB; plant; salinity stress; soil

\section{Introduction}

The worldwide enhancement of both human population and the associated environmental deterioration has the unfortunate influence that global food manufacture might soon become unsatisfactory to nourish all of the world's people. It is therefore crucial to increase farming productivity within the next few decades [1]. On the other hand, in the natural environment, plants are constantly exposed to various abiotic and biotic factors, which may affect their increase and yield [2]. Stress is described as any external abiotic (salinity, water, heat) or biotic (herbivore) constraint that restricts the level of photosynthesis and decreases a plant's capacity to transform energy to biomass [3]. Especially, abiotic factors are main constraints for global food security, food quality, and crop productivity [4]. 
Salinity is recognized to affect almost one fourth of world cultivable land, a main cause of desertification [5]. It is responsible for the degradation of 10 million ha of world farming per year [6], influencing about 1 million ha in the European Union, mainly in the Mediterranean countries. Various salt ions in the soil, that are dissoluble in water like chloride $\left(\mathrm{Cl}^{-}\right)$, sodium $\left(\mathrm{Na}^{+}\right)$, magnesium $\left(\mathrm{Mg}^{2+}\right)$, potassium $\left(\mathrm{K}^{+}\right)$, bicarbonate $\left(\mathrm{HCO}^{3-}\right)$, sulfate $\left(\mathrm{SO}^{2-}\right)$, carbonate $\left(\mathrm{CO}_{3}{ }^{2-}\right)$, and calcium $\left(\mathrm{Ca}^{2+}\right)$ may cause salinization [7]. Salinization is a natural process in semiarid and arid zones and may additionally be stimulated by anthropogenic practices. It significantly influences land fertility [8], and therefore comprises a huge effect on food security and economy at local, regional, and global levels [7]. Although plant tolerance to salinity varies with species and even varieties as well as with biotic and abiotic factors, the growth of most of the plant cultures is negatively influenced by salinity $[9,10]$. Excess accumulation of salts in the root zone often deteriorates the soil properties, viz. physical, chemical, and biological to such an extent that crop production is adversely affected [11]. In addition, excessive salinity in soil suppresses growth, decreases species diversity, and alters the community composition of plants; however, the effect of salinity on soil microbial communities is poorly understood [12].

Some of the microorganisms that live in close combination with the plant roots ensure a significant function in improving plant growth [13], and/or in stress mitigation of crops cultivated under salinity conditions [14]. Plant growth-promoting bacteria (PGPB) may be active through a diversity of processes [15] including the regulation of the transcription of various genes and cellular communication through quorum sensing [16], and mainly by production of various secondary metabolites [17]. For instance, through the production of exopolysaccharides (EPS), indole acetic acid (IAA), nitrogen fixation, and P-solubilization [18]. PGPB may form symbiotic relations with plants and improve their performance in the face of salinity stress $[19,20]$. Moreover, PGPB are an environmentally sustainable tool to mitigate the impacts of salinity on crop yields [2].

\section{Implication of PGPB on Soil Desalinization}

Soil hosts an enormous number of bacteria (often between $10^{8}$ and $10^{9}$ cells per gram of soil) but only about $1 \%$ of those bacteria are culturable [21]. Soil microorganisms belong to various groups of fungi, archaea, bacteria, and protozoa. Some of these microorganisms are recognized for their capacity to tolerate and improve plant salinity tolerance [22]. To date, several bacterial genera, like Streptomyces, Azospirillum, Clostridium, Alcaligenes, Bacillus, Rhizobium, Pseudomonas, Thiobacillus, Serratia, and Klebsiella are recognized as PGPB working under saline conditions [23]. They are being tested under field trials applied as a one species inoculant or as part of microbial consortia with very encouraging results [24].

They may alleviate salinity stress by resynchronization stress-stimulated physiological modifications in plants through different mechanisms [25,26]. Additionally, PGPB promoting impact during stress conditions has also been proposed to be advantageous for crop effectiveness, dry weight of root and shoot and root length, and the plant height [27]. The various ways in which microbes stimulate plant growth and alleviate stress responses include efficient nutrient mobilization in the soil, protection from phytopathogens, and improvement of soil structure and quality by sequestration of toxic heavy metals. Microbes can also aid degradation of various xenobiotic compounds [28]. The primary action of PGPM (plant growth promoting microorganisms) is investigated as their role in maintaining osmotic balance, ion homeostasis, and turgor pressure to combat the toxicity of salinity in plants [19]. The salinity-resistant microbial community improves the health of salinity-impacted soil, maintains ecological functions, and sustains and promotes the growth of plants [29]. Hence, the application of beneficial stress-tolerant microbes not only helps in improving the microbial community structure but also in enhancing plant and soil health under salinity. Further research will be required to reveal the hidden mechanisms of stress-tolerant microbial diversity [30]. Moreover, various researchers have demonstrated that the associations between rhizospheric microbes and stressed plants help the plants to adapt to their microenvironment [11]. 


\section{Impacts of Salinity on Crops}

All crops may be killed by salt solutions if the amount is excessive. The salinity of a field is such that individuals of a specific crop die, although most farming interests (and most research) are focused on the impacts of sublethal salinities. A wide spectrum of physiological and biochemical alterations of plants are induced by salinity, which causes lowered water potential in the soil solution, ionic disequilibrium, specific ion effects, and a higher accumulation of reactive oxygen species (ROS) [31]. Generally, the consequence of salinity was initially involved with $\mathrm{NaCl}$, as these ions are the most frequent reason for salinity in plants that have been established not in requirements of survival, nevertheless, in its impact on plant increase [32]. Notably, salinity may reduce crop productivity [32]. Biomass yield is adversely associated and rapidly reactive to osmotic stress whereas the potency of the subsequent membrane injury is determined by the level of salt fixation and the capacity to compartmentalize the salts in diverse tissues [33]. In addition, salt influences density and germination of plant cultures, and also crop development, decreasing yield, and, in the particularly difficult cases, causing widespread plant death, decreasing the attribute of the usable water and restricting absorption of nutrients [34]. It decreases grain productivity and seed set by affecting pollination. Seed germination in glycophytes is severely inhibited under salinity due to both osmotic stress and ionic toxicity stress [35]. In addition, in [36], several crops such as barley, cotton, bean, rice, and wheat reduce their productivity considerably during saline stress. Similarly, earlier investigation, in [37], mentioned a significant impact of salinity rates, varieties, and the correlations among yield and yield constituents in rapeseed. For instance, in [38], in tomato the exhibition of salinity stress results in $\mathrm{Na}^{+}$ aggregation in style, ovaries, and anther intermediate layers that generated an improved survival of the plant, level of flower abortion, and diminution of pollen number. In addition, several main field crops like rice (Oryza sative L.), wheat (Triticum aestivum L.), sorghum (Sorghum bicolor L. Moench), maize (Zea mays L.), sugarcane (Saccharum officinarum), and cotton (Gossypium hirsutum) show adverse reaction against salinity [39].

\section{Salinity Origin and Its Impacts on Plants}

Salinity is a cumulative process over time and may have a natural origin (Figure 1) or may be due to anthropogenic practices [39,40]. Different types of mineral salts $\left(\mathrm{Na}^{+}, \mathrm{K}^{+}, \mathrm{Cl}^{-}, \mathrm{Mg}, \mathrm{Ca}\right.$, etc. $)$ at the origin of salinity in the soil and can prevent impacts from several sources such as climatic factors (erosion and evaporation), and manufacturing. Hemophilic PGP (Plant growth promoting) bacteria present in soil can alleviate salt stress, stimulate vegetal nutrition and growth through enhancement of various vital plant mechanisms.

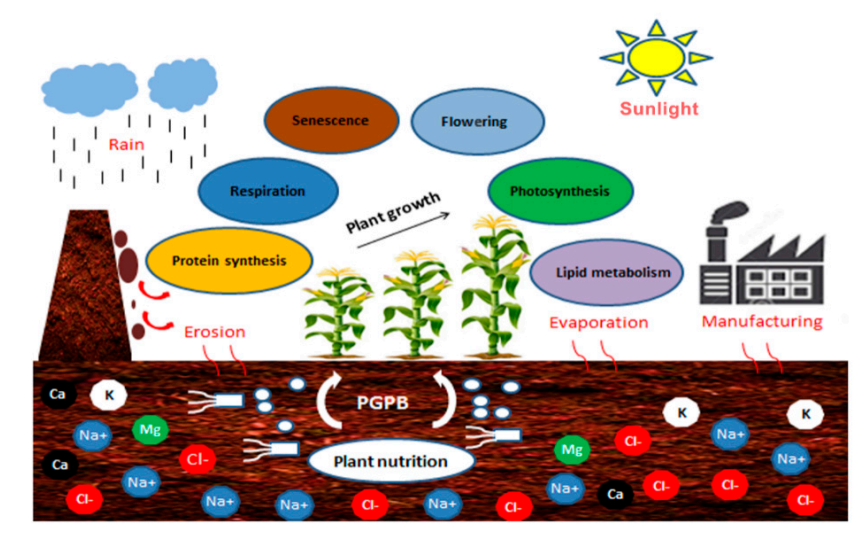

Figure 1. Origin of salinity in the soil and the main impacts of salicylic acid produced by PGPB (plant growth promoting bacteria) on plant primary metabolism.

Salinity is a consequence of inorganic salt solubilization, dust deposition, unbalance between precipitation and evapotranspiration rates, or an increased capillary infiltration of saline underground 
water [41]. Salinization affects plant development when salt concentrations build up in the root zone [40]. To maintain productivity under saline conditions, crops need higher water and fertilizer inputs, which probably enhances soil salinity in the end [5], extending the zone affected by secondary salinization [42].

Salinity is a two-phase stress to plants comprising a rapid osmotic phase followed by a slower one related with ion accumulation [43]. During the first phase, salinity elicits disorder of water and ionic homeostasis increasing the energetic costs of cellular metabolism [44,45] affecting, among others, nutrient uptake [46,47], photosynthesis and respiration [48], lipid metabolism and protein synthesis [49,50], phytohormone production, oxidative stress, gene expression, and long distance transport [51], which affects plant seed germination and seedling survival, as well as plant phenotype. The plant osmotic response of salinity stimulates physiological modifications in the plant that are similar to those generated by water stress [52]. Apart from its influence in plant biomass accumulation, salinity may interfere in the process of biomass partitioning between shoots and roots [44].

Plant resistance or tolerance to salinity involves the root capacity to restrain $\mathrm{Cl}^{-}$and $\mathrm{Na}^{+}$uptake or to induce their efflux, while maintaining the adequate uptake rates of essential ions such $\mathrm{NO}_{3}$ and $\mathrm{K}^{+}[51]$, which may be associated with the accumulation of compatible solutes such as proline and soluble sugar able to participate in the osmotic balance [45-53]. With varying salt concentrations, transcription of genes responsible for osmoprotectant synthesis may express differentially in some HT-PGPR (Halo-tolerant plant growth promoting rhizobacteria). For example, in Bacillus. amyloliquefaciens FZB42 trehalose and proline synthesis were found to be differentially expressed at 0 and $100 \mathrm{mM} \mathrm{NaCl}$ concentrations facilitating stress adaption in A. thaliana [54].

\subsection{Seed Germination}

Plants exhibit great variability toward salinity resistance [55,56]. Many seeds, including those of L. cossonianum, present their highest germination rate in distillated water and are extremely sensitive to salinity $[57,58]$. Salinity delays the germination process in a process that is dependent on abiotic and biotic factors such as light, temperature [59,60], and plant microbiome [61]. Overall, salt stress adversely influenced seed germination; both osmotically via decreased water absorption or ionically via the accumulation of $\mathrm{Cl}^{-}$and $\mathrm{Na}^{+}$causing toxicity impact and an imbalance in nutrient uptake [61]. It affects the sowing increase of plants by less or slow mobilization of preserve foods, suspending the division of cells, injuring and enlarging hypocotyls [62]. For instance, germination percentage in Lettuce (Lactuca sativa) showed substantial reduction with cumulative salinity up to $14.1 \mathrm{dS} \mathrm{m}^{-1} \mathrm{NaCl}$. The essential time for germination likewise increased with increasing salinity levels. The seedling growth was meaningfully repressed [63]. Furthermore, the study conducted by Bagwasi et al. [64], showed that salinity influenced seed germination of different wheat and barley cultivars. Although, all cultivars showed a reduction in total germination percentage, with increasing salinity levels from EC 0 to EC $20 \mathrm{dS} \mathrm{m}^{-1}$. Wheat cultivars outperformed barley cultivars at EC levels $0,4,8,12$, and $16 \mathrm{dS} \mathrm{m}^{-1}$.

\subsection{Primary Metabolism}

While a plant endures abiotic stress, a variety of genes are switched on or off, leading to changes in many metabolites and proteins, responsible for triggering salinity stress defense [65].

\subsubsection{Photosynthesis}

Photosynthesis is a major essential physiological process and is potentially influenced by salinity at all stages $[66,67]$. However, disentangling the cause-effect nexus between photosynthesis inhibition and decline in sink demand due to salinity is controversial. Many roads lead to photosynthesis inhibition by salinity including increased oxidative stress-related impacts [68], changes in chlorophyll concentration [69,70], and osmotic stress. The water deficit associated with salinity induces a reduction in leaf cells turgor and the concomitant stomata closure, decreasing stomatal 
conductivity (gs) and the intrinsic $\mathrm{CO}_{2}$ concentration, which leads to reduced carboxylation rates by RuBisCo (ribulose-1,5-bisphosphate carboxylase) [69]. Moreover, the response of the sesame (Sesamum indicum L.) plants to salinity stress was analyzed by estimating the levels of photosynthetic enzymes activity. Photosynthetic rate, activities of RuBisCo, and sucrose phosphate synthase (SPS) decreased with increasing salinity. In addition, the activities of Dichlorophenol Indophenol (DCPIP) reduction were decreased [71].

\subsubsection{Respiration}

Respiration and mitochondrial metabolism ensure a central function in establishing plant salinity resistance like ion removal, osmotic resistance, and ROS (reactive oxygen species) responses [72]. Salinity has been shown to contribute to increased respiration levels in a large variety of plant species [73,74]. In some cases, the increase in the respiration rate is related with changes in the plasmalemma composition and permeability, higher protein turnover [75], and higher energetic costs associated with ion homeostasis. Nevertheless, respiration itself can be inhibited by salinity through distinct sensitivity of the enzymes involved in the respiration pathway towards salinity [76,77]. For example, salt treated wheat leaves exhibit higher respiration rate and extensive metabolite changes. The activity of the tricarboxylic acid (TCA) cycle enzymes pyruvate dehydrogenase complex and the 2-oxoglutarate dehydrogenase complex were shown to be directly salt sensitive. Multiple lines of evidence showed that the $\gamma$-aminobutyric acid (GABA) shunt was activated under salt treatment [78].

\subsubsection{Senescence}

Under long-period exposition to salinity, plants undergo ionic stress, which may contribute to premature senescence of mature foliage and hence a decrease of the required photosynthetic zone to maintain biomass accumulation and growth $[79,80]$. Salt-stimulated senescence is claimed to be due to ionic pressure of high $\mathrm{Na}^{+}$quantities and nutritional deficiencies like a decreased cytoplasmic $\mathrm{K}^{+}: \mathrm{Na}^{+}$ proportion $[81,82]$ causing chlorosis and necrosis in mature leaves by destruction of protein production and disruption of enzyme function [83]. In rice leaves, salinity affects several senescence-related variables including membrane permeability, fluorescence of chlorophyll a, and leaf concentration of chlorophyll and protein. The anticipation of increased activity of senescence characteristic enzymes such as isocitrate lyase (ICL) can be observed under saline conditions $[84,85]$. The involvement of ICL, a central enzyme of the glyoxylate cycle [86], in the crossroads between salinity and senescence was demonstrated in an experiment showing that the AtICL knockout tomato (Aticl mutant without ICL activity) was much less tolerant to salinity than the isogenic wild type [85].

\subsubsection{Flowering}

Flowers produced higher P and Zn comparably to the control crops, while the targeted vegetation was exposed to either salinity levels. Salinity reduced the composition of $\mathrm{Mg}$ in flowers at $100 \mathrm{mM}$ $\mathrm{NaCl}$ concentration. Interestingly, $50 \mathrm{mM} \mathrm{NaCl}$ salinity generated $\mathrm{Ca}$ in flowers approximately three times relative to the control of crops not treated with salt [87]. In addition, phonological findings of bud flowering and forming were found in plants handled with high amounts of $\mathrm{NaCl}$ occurred in contrast to control plants [88]. For instance, in [89], with rising salinity rates, days to flowing were expanded, however, in rapeseed rice varieties days to maturation were reduced. Additionally, early flowering in plants species decreased dry matter, enhanced root, shoot ratio as a response to salinity stress [90]. On the other side, plant tolerance to salinity stress requires biochemical modifications in the metabolism of nitrogen and carbon including improvements in proline and polyamines [91]. Production of polyamines in bacteria and plants starts with the production of putrescine, diamine, from decarboxylase ornithine (ODC) or arginine decarboxylase (ADC). During vegetative growth ADC activation was correlated with smaller internodes, necrotizing and (in one line) rapid flowering [92]. Additionally, differences in flavonoid, polyphenol, and pro-anthocyanidin compositions have been 
observed in C. tinctorius flowers during salt stress at two improvement phases including full and post flowers formation [93].

\subsubsection{Protein Synthesis}

Many plants respond to salinity through modifications in their protein status. Salinity may interfere with the regulation of protein activity, protein synthesis, and even with the availability of the substrates needed for protein synthesis (namely N). Cellular suspensions of Nicotiana tabacum and Citrus sp. plants sensitive to salinity have distinct proteomic profiles under saline and non-saline conditions [94]. The disturbance of protein synthesis tends to be a major cause of $\mathrm{Na}^{+}$damage [82]. Similarly, high $\mathrm{Na}^{+}$ concentration or $\mathrm{Na}^{+}: \mathrm{K}^{+}$ratio may disturb several enzymatic mechanisms. $\mathrm{K}^{+}$stimulates and/or regulates the activity of more than 50 enzymes and is a critical component of the protein synthesis as it attaches tRNA to ribosomes [95].

Salinity inhibits root nitrate uptake [96] and thus the availability of $\mathrm{N}$ needed for protein synthesis [97,98], as it was evidenced by the decrease of free amino acid concentration in Glycine max roots under salinity [99]. However when grown under saline conditions tolerant plants may increase the concentration and/or the activity of key proteins that contribute to salt resistance reactions, such as heat shock proteins (HSPs), ribulose-1,5-bisphosphate carboxylase (RuBisCo), antioxidative enzymes, late embryogenesis abundant (LEA) proteins, glycerate dehydrogenase, glucose-6-phosphate 1-dehydrogenase, glutamate synthase, NADPH-producing dehydrogenase, and glutamine synthetase [100].

\subsubsection{Lipid Metabolism}

The fine tuning of plant lipid profile is a key tool in crop adaption to environmental changes, but the process by which lipid contouring modulates a respond to salt stress is not clear [101,102]. Salinity causes structural changes in the lipid composition of the plasma membrane, like increasing the degree of free fatty acid saturation and enhancing concentration of free sterols, leading to a reduction in cellular membrane fluidity [103]. For example, the lipid composition of the root plasma membrane of Phaseolus vulgaris grown under salinity differed in phospholipid groups, saturated and unsaturated fatty acids, and sterol groups from that of plants grown under non-saline conditions [104]. Furthermore, the intensity of salinity induced a considerable decrease in overall lipids derived from the black cumin seed [105].

Salinity induced oxidative stress in C. roseus cells, as seen by the rise in lipid peroxidation, increased lipoxygenase (LOX) function, following antioxidant enzyme activation [104]. Plant response to salinity may decrease the concentration of sterol ester, oleic acid, and free fatty acids, and reduces that of linoleic acid $\left(\mathrm{C}_{18} \mathrm{H}_{32} \mathrm{O}_{2}\right)$ and triacylglycerol [106]. Under salinity, the expression of the genes involved in the lipid metabolism may suffer changes [107]. Novel discoveries have greatly expanded the importance of autophagy during lipid metabolism. An emerging model suggests that autophagy can operate in various aspects of lipid and membrane recycling. Current evidence also highlights the complexity of this system, given that autophagy is required for energy-producing organelle maintenance under stress conditions. This is of paramount importance because the removal of damaged and potentially ROS over producing energy organelles can circumvent cell death and promote lipid catabolism [108].

\section{Impacts of Salinity on Soil}

The remediation of salt-affected soils is difficult and costly [109], if not impossible. Globally, salinity has a negative effect on crucial soil mechanisms like respiration, degradation of residues, denitrification, nitrification, root function, and soil biodiversity [110], by affecting crucial soil enzyme activities during stress that were implicated in soil degradability, nutrients cycling, organic matter composition, and intercellular metabolic responses of living organisms [34]. The activity of soil enzymes tends to decrease with salinity, despite the rate of inhibition being variable according to the enzyme and the salinity level [111]. Salinity and, in particular, sodium contributes to soil degradation, particularly of clay agglomerates, 
which generally leads to structure loss, reduced hydraulic conductiveness, disrupted air and water flow, erosion, and run off [112].

Salinity may lead to higher soil moisture content; however, it significantly decreases the osmotic potential of the soil solution, resulting in lower water absorption by the plants and other living organisms [113]. A soil may be identified as salt-impacted when white salt-cross and/or salt-spots are present on/in the bare soil; there is persistent or sustained waterlogging following rainfall; crumbling and road erosion are visible; surface water is unpalatable to animals and humans; and the appearance of salt crystals under extremely saline lands [114].

Salinity affects the distinct functional characteristics (biological, chemical, and physical) making soil recovery very difficult. In contrast with other current alternatives, organic fertilization seems to be extremely efficient as a mitigation solution to the problems outlined above [115]. For instance, saline-sodic soil has many negative characteristics including high values of electrical conductivity (EC), sodium adsorption ratio (SAR), and exchangeable sodium percentage (ESP) [116]. Additionally, high levels of soil salinity and sodicity can limit the activities of enzymes and microbes [117].

\subsection{Soil Biological Activity}

Salts are an important component of soil, and certain salts (e.g., nitrates, sulfates, phosphates) are critical for soil fertility [118]. Salt-impacted soils contain high concentrations of soluble salts in both the micro and macro-pores [119]. Therefore, soil salinity inhibits soil respiration and $\mathrm{C}$ mineralization, as demonstrated by lower the $\mathrm{CO}_{2}-\mathrm{C}$ evolution rates of saline soils in comparison to non-saline soils [120]. Similarly, the osmotic potential of the soil solution increases and thus minimizes the potential plant and microbial water availability [121]. Saline soils have higher permeability to soluble salts and lower potential assimilation rates of nutrients like N [122]. Additionally, the absorption of nutrients is inhibited by ion competitiveness and higher $\mathrm{pH}$, whereas the weak soil structure generated by high sodium levels adversely affects soil water quality and plant growth [123].

\subsection{Soil Microbial Function and Diversity}

In good conditions, $1 \mathrm{~g}$ of soil may incorporate 600 million bacteria appertaining to 15,000 or 20,000 distinct species. These amounts reduce to 1 million bacteria in desert soils comprising between 5000 and 8000 species [124]. This soil microbiota plays a vital role in preserving and/or improving the consistency of the soil by controlling the degradation of organic matter and the supply of nutrients, facilitating the production of macro-aggregates [125]. However, soil microbiota responsible for the formation and maintenance of soil aggregates are vulnerable to environmental changes because of their wide area to volume ratio, highly permeable cell membrane, and high turnover rates resulting in a quick reaction to nutritional supply variations [126].

It is evident that salinity decreases microbial activity, microbial modifications, biomass, and the structure of the microbial community $[127,128]$. Furthermore, knowing the microbial group structure and its role in saline soil is a key ecological goal, as it will help to explain the biological regulatory processes for the nutritional cycles in saline soil [129]. Many other studies concentrate on the examination of the effects of salinity on microbial communities [130,131]. Salinity has an adverse effect on quantity, distribution, structure, and functionalities of the microbiota [132]. Additionally, salinity was observed to lower soil microorganism's biomass and microbial growth rate [133,134]. The disruption of the symbiotic relationship between plant and microorganisms is another damaging consequence of salinity. For instance, disruption in plant interaction with bacteria is induced by deterioration in proteins implicated in the anchoring and adsorption phases of the symbiotic interactions between bacteria and plant roots [135]. Salinity often has an adverse impact on biotransformation of the biogeochemical cycles like mineralization of $\mathrm{N}$ and $\mathrm{C}$ [129]. Microbes are engaged in nitrification, oxidation, ammonization, nutrient absorption, and other processes that contribute to soil organic matter nutrient cycling and degradation [136]. 
Fungi are usually considered to be less salinity tolerant than prokaryotes. However, this claim is only because only prokaryotes are tolerant to extreme levels of salinity [137]. However, in fact, the total number of soil fungi is significantly reduced with increased levels of salinity. The total number of Actinobacteria and bacteria also decreases under salinity, but only at salinity levels above $5 \%$ [138]. The low osmotic potential characteristic of soil salinity declines hyphae production and spore germination, and induces modifications in the mycelium morphology [139]. Archaea is one of the microbial groups reported to increase its relative abundance in extremely saline ecosystems. However, the functional relevance of the association between plants and archaea is still unknown, since only a few reports of the association between archaea and plants (rice, maize cress, Abutilon, Suaeda nudiflora, and Sporobolus) have been established [140,141].

\section{Halophile PGPB for Sustainable Agriculture}

In the rhizosphere, plant-microorganism relationships are indicators of plant health, production, and soil fertility. Particularly, plant growth-promoting bacteria (PGPB) are microorganisms that could also promote plant increase and prevent plants from infection and abiotic factors via a wide range of processes. Those PGPBs that develop more intimate interactions with plants, like the endophytes, may be more effective in plant growth improvement [16]. Usage of PGPB as an important part of farming activity is an innovation whose time has arrived [1]. More particularly, some halophilic bacteria were proved able to alleviate plant salt stress, improving the development and productivity of crop production under salinity [142].

PGPB represent a possible solution to mitigate salinity-induced plant stress [143]. The impact of five plant growth stimulating halotolerant bacteria on wheat growth [142] revealed that bio-formulation of these halotolerant bacterial strains can improve salinity stress $(80,160$, and $320 \mathrm{mM})$ in wheat seedlings, resulting in a $70 \%$ improvement of root length comparatively to negative controls. In addition, variations in the bacterial community formulation with the soil salinity were observed, and attention is growing in experiments regarding functional interactions between plants and microbes that lead to salt stress tolerance [25]. The use of microorganisms for saline soil restoration may be an environmentally sustainable, safer, and more efficient method, as the halophilic microorganisms have the potential to eliminate salt from saline soils [144]. Such microbes also provide exceptional prototypes for studying the stress resistance, adaptation, and response processes which might consequently be integrated into agricultural crops to cope with the pressures caused by climate modification [145].

\subsection{Biofertilization}

PGPB can successfully be manipulated in the agro-farming system as alternative strategies to control most of the stated abiotic stresses faced by crops and to increase their yields and would lead to the minimal use of synthetic fertilizers [146]. Arbuscular mycorhizae fungi and plant growth promoting bacteria are beneficial microbes in the soil which provide assistance to plants in many ways. Directly they are concerned with hormones and organic compounds synthesis while indirectly they reduce salinity stress. They can be employed in agriculture as biofertilizers [147]. Improved plant growth under saline soils has been attained with the use of PGPB [148]. Significant increase in growth attributes of rice plants with Bacillus amyloliquefaciens as compared to non-inoculated control plants under salinity stress [149]. Bacillus licheniformis SA03 inoculated with Chrysanthemum plants grown under saline-alkaline conditions significantly decreased saline-alkaline stress in plants along with augmented biomass and survival rates via mediating cellular ABA (abscisic acid) levels [150].

\subsection{Biopesticides}

Many strains of PGPB have been found to be positively linked with suppressing diverse plant pathogens (both in the rhizosphere and above ground) by producing antagonistic metabolites and enhancing the immunity potential of crops to pathogenic stress [151]. Moreover, Nadeem et al. [152] have comprehensively provided evidence about the growth promotion and biocontrol potentials of 
AMF and PGPR in agriculture. Egamberdieva et al. [153] found that Pseudomonas chlororaphis TSAU13 and P. extremorientalis TSAU20 reduced the Fusarium infection by $23 \%$ and $14 \%$ under non-saline conditions and by $42 \%$ and $25 \%$ under saline conditions, respectively. Tewari and Arora [154] reported EPS (exopolysaccharides) and salicylic acid producing P. aeruginosa PF23EPS+ showed biocontrol against $M$. phaseolina up to $500 \mathrm{mM} \mathrm{NaCl}$.

\subsection{Bioremediation}

The concept of using PGPB to facilitate bioremediation of contaminated soil has only recently emerged. For example, Pacwa-Płociniczak et al. [155] proposed that two petroleum hydrocarbon-degrading Rhodococcus spp., with plant growth promoting traits, are likely to be good candidates for the phytoremediation of petroleum hydrocarbon contaminated sites. In recent years, the ecological functions of halophyte symbiotic microorganisms, including the growth promotion of host and crops, enhanced salt tolerance, and joint phytoremediation of contaminated soil, have been clarified by increasing studies $[156,157]$. As bioremediation agents, Streptomyces (in particular halophiles), participate in alleviating the toxic effect of xenobiotics on plants, using the strategies previously mentioned. Streptomyces are widely used in the remediation of soils contaminated with different pollutants. Moreover, they are studied as PGP in salt-affected soils, where they provide plants with salt resistance to face this major problem for agriculture [158,159].

Table 1 illustrates various roles of PGPB in enhancing yield and growth of different plants/crops under salt stress.

Table 1. Various roles of PGPB (Plant growth promoting bacteria) in enhancing yield and growth of different plants/crops under salt stress.

\begin{tabular}{|c|c|c|c|c|}
\hline Crops & PGPB & $\mathrm{NaCl}(\mathrm{mM})$ & Beneficial Effects & Reference \\
\hline Lettuce & Azotobacter chroococcum & 50 and 100 & $\begin{array}{l}\text { Enhanced the radicle lengths and plumule of } \\
\text { germinated seeds }\end{array}$ & [160] \\
\hline Strawberry & Bacilus sp. & 35 & $\begin{array}{l}\text { Ameliorated fruit productivity, leaf water amount, ionic } \\
\text { constitution, and membrane permeability }\end{array}$ & [162] \\
\hline Maize & $\begin{array}{l}\text { Trichoderma } \\
\text { harzianum Th-6 }\end{array}$ & 50-150 & $\begin{array}{l}\text { Improves water composition and stomatal conductance, } \\
\text { elevated pigment amounts, and increases photosynthetic } \\
\text { performance }\end{array}$ & [164] \\
\hline
\end{tabular}

\section{Mechanisms of PGPB (Plant Growth Promoting Bacteria) towards Salinity Tolerance}

The key mechanisms involved in PGPR (plant growth promotion rhizobacteria) salinity tolerance include specific membrane or cell wall structures, draining ions out of the cell through salt efflux, or modification of their intracellular environment through accumulation of nontoxic organic osmolytes, and adapting enzymes and proteins to function under high solute ion concentrations [25]. The ability of PGPB to improve crop yields during salt stress includes many direct and indirect pathways such as ferrous iron minerals and inorganic phosphate solubilization, exopolysaccharides and biofilms synthesis [166], production of phytohormones [167], increased ACC (1-aminocyclopropane-1-carboxylate) deaminase activity [168], and nitrogen fixation [169]. The Figure 2 shows PGPB (Plant growth promoting bacteria) salinity resistance strategies and mechanisms of plant growth improvement under salt stress. PGP bacteria may survive high salinity via three main mechanisms (pumping out the cell, intracellular adaptation processes, and cell wall construction). These bacteria stimulate plant growth during salt stress by means of several mechanisms including 
phytohormones production, amelioration of nutrients uptake, ACC deaminase, P solubilization, EPS synthesis, biofilms formation, and $\mathrm{N}_{2}$ fixation.

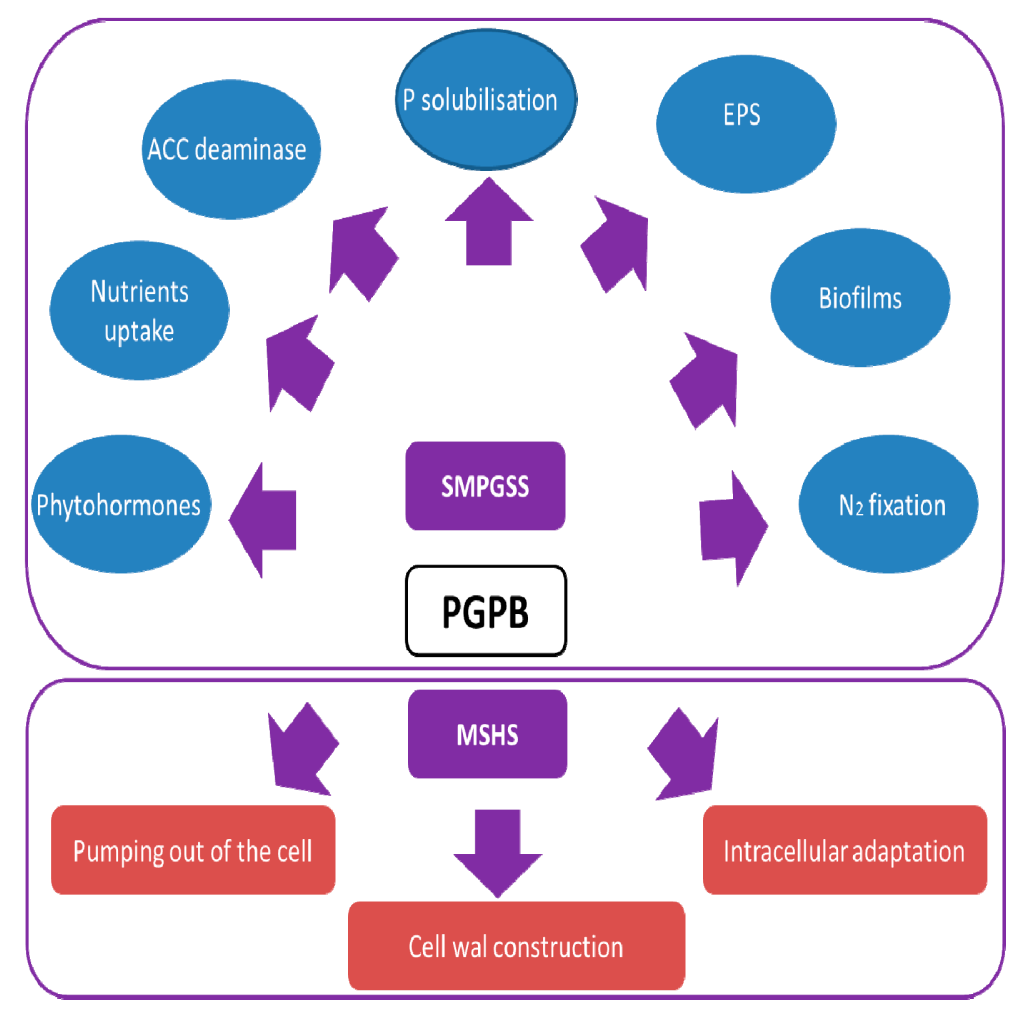

Figure 2. PGPB (Plant growth promoting bacteria) salinity resistance strategies and mechanisms of plant growth improvement under salt stress (SMPGSS: stimulation mechanisms of plant growth under salt stress; MSHS: mechanisms surviving high salinity, PGPB: plant growth-promoting bacteria, EPS: exopolysaccharides).

\subsection{Direct Mechanisms}

\subsubsection{Nitrogen Fixation}

Nitrogen is an essential plant nutrient [170]. In particular, legumes are influenced by salt stress frequently related to a lower growth of the host plant, weak symbiotic formation of root-nodule microorganisms [171] with a decrease of the nitrogen-fixing capacity [172]. Symbiotic associations of plants with soil microbes such as nitrogen-fixing bacteria (Frankia and Rhizobia) and mycorrhizal fungi may have a positive impact on plant salt stress tolerance [173]. Additionally, stress-tolerant rhizobial strains may help legume plants to preserve the level of $\mathrm{N}$ fixation and plant productivity [174]. Salinity tolerant Rhizobium bacteria are more efficient in promoting plant growth under saline conditions [175]. Consequently, it is advisable to select indigenous rhizobial strains that are efficient even under salinity [176]. For example, A. nilotica inoculated with a salinity resistant Rhizobia strain was capable of maintaining an $\mathrm{N}$-fixing rate of almost $70 \%$ at $12 \mathrm{dS} / \mathrm{m}$ compared to its highest fixing rate $(2 \mathrm{dS} / \mathrm{m})$ [177]. The simultaneous treatment of cowpea seedlings with arbuscular mycorrhizal fungi (AMF) and $\mathrm{N}$-fixing bacteria like Azospirillum brasilense enhanced plant $\mathrm{N}$ concentration by $230 \%$ in comparison to $151 \%$ and $94 \%$ in seedlings treated individually with $\mathrm{N}$-fixing strains or AMF at $7.2 \mathrm{dS} / \mathrm{m}$ salinity [178]. It has been shown that the association of stress-tolerant varieties and stress-tolerant rhizobia can lead to synergistic benefits in legume plant development under saline conditions [179]. 


\subsubsection{Phosphate Solubilization}

Phosphorus (P) is another essential nutrient needed by living organisms for transduction, biosynthesis of macromolecules, energy transfer, respiration, and photosynthesis [180]. Most of the soil phosphorus is found in the form of insoluble phosphates and phytate, which cannot be used by plants [181]. Environmental factors are likely to affect the organization and efficiency of phosphate-solubilizing microorganisms, particularly under conditions [182], namely the efficiency of soil bio weathering of phosphates [183]. Recently it was highlighted that many microorganisms (Pseudomonas, Erwinia, Achromobacter, Enterobacter, Flavobacterium, Serratia, Mycobacterium, Bacillus, Escherichia, and Agrobacterium) improve their inorganic phosphate solubilization rates when $\mathrm{NaCl}$ is present in moderate concentrations [184]. However, this beneficial effect of moderate saline conditions is counterbalanced by the fact that salinity diminished the phosphorus adsorbed to soil particles and inhibits phosphate absorption by plant roots [185].

Some PGPB are able to solubilize phosphate salts at high salinity levels $(10 \% \mathrm{NaCl})$ [186]. It is possible that this efficiency of PGPB under high salinity is related to the fact that the production of organic acids responsible for phosphate solubilization (2-ketogluconic, gluconic, oxalic, acetic, citric, succinic, and malic acids), are also responsible for a local decrease of the alkaline $\mathrm{pH}$ usually associated with saline soils $[187,188]$. For instance, the isolate Pseudomonas stutzeri SGM-1 could grow at increasing salt concentrations up to $12 \% \mathrm{w} / \mathrm{v} \mathrm{NaCl}$ with wide temperature and $\mathrm{pH}$ ranges. Pseudomonas stutzeri SGM-1 exhibited diazotrophy by growing on nitrogen free media along with expression of other PGP traits such as phosphate solubilization. The amelioration of the salt stress to the Cicer arietinum plant by isolate's bio-fertigation was observed up to $300 \mathrm{mM}$ of $\mathrm{NaCl}$ [189]. A novel halo-tolerant strain Kocuria rhizophila Y1 was isolated from maize rhizosphere soil. This strain tolerated up to $10 \% \mathrm{NaCl}$ and showed growth promoting traits like phosphate solubilization [190].

\subsubsection{Production of Phytohormones}

Phytohormones play a crucial role in plant development and responsiveness to stress [191]. External phytohormones may help to improve crop productivity by improving biotic and abiotic stress tolerance [192]. Phytohormones like salicylic (SA), abscisic acid (ABA), and jasmonic acids (JA) also play key functions in plant response to salinity $[193,194]$. Particular enzymes that facilitate seed germination and plant development are also responsible for enhancing the concentration of certain phytohormones such as gibberellins (GAs) and indle-3-acetic acid (IAA) [195]. IAA is the major natural auxin with a well-documented capacity to control certain aspects of plant performance [196].

IAA is involved in cell division and extension; and root initiation. The regulation of these processes by IAA is negatively affected by saline conditions. Declining concentrations of IAA in the seedling roots of constrained plants result in reduced and slower germination rates [197]. Additionally, IAA can promote plant defense, for instances application of exogenous IAA decreased tomato infection by Fusarium oxysporum $f$. sp. radicis-lycopersici [198]. For example, the IAA producing ability under salt stress was assessed was observed to be $250 \pm 0.1,220 \pm 0.1$, and $200 \pm 0.1 \mu \mathrm{g} / \mathrm{mL}$ for Rheinheimera sp., Rhizobium sp., and Bacillus subtilis, respectively [199].

Phytohormones, e.g., Gas and IAA, are considered as growth hormones, which enhance the number of root tips, as well as root and shoot length resulting in improved nutrient absorption and thus improved plant health during stress and non-stress conditions [200]. It is recognized that phytohormones synthetized by bacteria may contribute to determining plant phenotype [201]. In addition, $\mathrm{PGPB}$ modulates ABA biosynthesis and ABA regulated signaling pathways, which can lead to increased salt-stressed crop production. Halotolerant Dietzia natronolimnaea STR1 stimulated salinity $(150 \mathrm{mM} \mathrm{NaCl})$ tolerance in rice seedlings through regulation of the ABA signaling cascade [24]. Novosphingobium sp. and Pseudomonas putida are reported to decrease salinity stress in citrus seedlings by enhancing leaf IAA concentration and decreasing accumulation of root chloride under salt stress [202]. Phytohormone signaling cascades influence osmotic equilibrium and other processes of salt resistance and control adaptation of plants to salinity $[197,203,204]$. Auxin-producing root-colonizing bacteria 
can provide additional auxin to the rhizosphere, and can help root development during stress, while maintaining leaf growth [205].

\subsubsection{Exopolysaccharides and Biofilm Formation}

In many salt tolerant bacteria, the formation of exopolysaccharides (EPSs) is a strategy for growth, adherence to solid areas, and survival of adverse conditions. In particular, the synthesis of exopolysaccharides by these bacteria can also lead to stress reduction, in addition to improving their salinity-condition survival and competence [206]. Certainly, they have a defensive character: EPSs, which generate a layer around a cell, provide powerful defense towards elevated salinity [207]. EPSs are the most crucial component of extracellular matrix, representing $40-95 \%$ of bacterial weight [208]. They are located on microbial cellular surfaces where the cells are preserved by stabilizing membrane organization toward unfavorable environmental stresses. They are mainly formed by large organic macromolecules; polysaccharides, along with smaller uronic acid and protein percentages [209]. Microorganisms to protect themselves against ionic toxicity and desiccation form polysaccharides, most of them are in the ionic form contributing to chelate and sodium ions. This decreases the toxicity and concentration of such ions in the rhizosphere, rendering the soil ideal for root proliferation [54-210].

Increased exopolysaccharides generation in response to salt stress favors biofilm formation [211,212], contributing towards plant adaptation to salinity [213]. In addition, biofilms are formed on specific surfaces, such as roots and soil particles, contributing to reinforce soil structure and physicochemical characteristics [214,215]. The fact that Pseudomonas anguilliseptica SAW 24 exhibited the maximum PGPB effectiveness at its maximum biofilm formation capacity confirms the relation between biofilm formation and PGPB effectiveness under saline and non-saline conditions [215]. Halophilic microorganisms can form biofilm and accumulate EPS at increasing salt stress. EPSs promote bacterial colonization of plant roots and soil particles, and they can eventually be added to soil to improve its structure and, consequently, to improve plant growth. In a long-term vision, alleviation of derelict soil, improved crop yield, and restoration of mangrove diversity are possible by mechanistic use of EPS-producing halotolerant microorganisms [216]. For instance, Fathalla [216] showed that biofilm formation and EPS-production by $\mathrm{Az}$. chroococcum significantly contribute to soil fertility and improve plant growth.

\subsubsection{Enhancement of Plant Nutrient Uptake}

The excessive uptake and respective accumulation of ions may result in toxicity. Salinity is particularly associated with high $\mathrm{Na}^{+}, \mathrm{Cl}^{-}$concentrations, the persistence of excessive concentrations of these ions in the soil may disturb ion balance in soil solution, and uptake by the plant roots [217]. High sodium and chloride concentrations in the soil can create $\mathrm{Na} / \mathrm{K}$ and $\mathrm{Na} / \mathrm{Ca}_{2}$ unbalances in crop plants responsible for increased susceptible to osmotic stress and lower yields [218]. Especially, high concentrations of $\mathrm{Na}^{+}$in the soil solution inhibit $\mathrm{K}^{+}, \mathrm{N}$, and $\mathrm{Ca}^{2+}$ uptake [219]. Plant growth-promoting bacteria also release/increase the availability of mineral elements like $\mathrm{Cu}$, $\mathrm{Fe}, \mathrm{Mn}, \mathrm{Zn}$, etc., to plants by chelation and acidification of soil [220]. For example, potassium has a significant role in the growth and development of the plant. To achieve maximum yield, $\mathrm{K}$ is needed in adequate quantities (50-300 $\mathrm{kg} \mathrm{ha}^{-1}$ ) by all crops. However, most of the $\mathrm{K}$ of soil is not directly available for plant uptake. Moreover, $\mathrm{K}$ availability to plants decreases due to salinity stress. In this situation, K-solubilizing bacteria (KSB) are an effective tool to fulfill the $\mathrm{K}$ requirement of crops [221].

PGPB enhance crop development and thereby increase the availability of mineral nutrients to plant roots [222]. For example, PGPBs from Rhizobium and Serratia genus were shown to be able to increase the nutrient absorption of lettuce growing under different soil salt concentrations [222,223], and several isolates of Azospirillum sp. and Pseudomonas sp. were shown to improve the development and biomass of canola plants by ameliorating essential nutrients uptake under saline conditions. There is now increasing recognition that the use of PGPB could enhance plant resistance to adverse nutrient deficiency [224]. Although, PGPB functions in nutrient availability and stress mitigation are 
emerging areas of farming that are not yet well established; it is accepted that they are a potential tool to improve productivity and sustainability in many areas of the world [225].

\subsubsection{Osmolytes Accumulation}

Under salinity, a higher fraction of the cellular energy deviated towards the synthesis of osmolytes is able to defend the cells from osmotic fluctuations [226]. In response to osmotic stress induced by high concentrations of $\mathrm{NaCl}$, bacteria may reprogram their gene expression and synthesize specific stress proteins [227]. In some halophilic bacteria, the internal amount of organic osmolytes can reach $1 \mathrm{M}$ under salt stress and has a significant function in lowering the Tm (Temperature of Melting) of DNA and stabilizing the double helix [228]. Consequently, bacterial cells accumulate compatible solutes, like amino acids, sugars, and quaternary amines, which prevent degenerative processes and improve cell growth under harmful osmotic conditions [229]. They host various groups of compounds comprising soluble sugars like trehalose, sucrose [230], celllobiose, maltose, turanose, palatinose, and gentiobiose [231]. In addition, sucrose, glycine, betaine, and proline are among the osmolytes greatest investigated and that are accumulated during salt stress in a number of plant species regrouping halophytes [232]. Notably, compatible solutes exert their influence by modifying the solvent structure and/or slight modifications in the dynamic characteristics of the protein, rather than by altering the protein structure itself [233]. Such osmolyte accumulations preserve turgor pressure and balance the different macromolecular structures towards the physiological drought stress caused by salinity [234]. These organic solutes can be generated in the cytoplasm where they help to maintain turgor and preserve enzymes and cell organelles from deterioration or dehydration [235].

\subsection{Indirect Mechanisms}

\subsubsection{ACC Deaminase}

Some microorganisms possess the enzyme 1-aminocyclopropane-1-carboxylate (ACC) deaminase that transforms 1-aminocyclopropane-1-carboxylic acid (the immediate precursor to ethylene biosynthesis in higher plants) into ammonia and $\alpha$-ethylene chetobutyrate instead of ethylene [236]. Additionally, as the enzyme ACC deaminase breaks the ethylene substrate ACC, which is transformed into alpha-ketobutyrate and ammonium, it supplies the microorganisms with $\mathrm{N}$ [237]. PGPB such as Rhodococcus, Variovorax, Alcaligenes, Bacillus, and Ochrobactrum have been identified to synthesize ACC deaminase [238], and have been shown to improve plant nodulation under salinity [239]. Recent findings on the synergetic functioning of ACC deaminase and other bacterial mechanisms of salt stress tolerance, such as trehalose accumulation, are also established [240].

ACC deaminase based PGPB can also reduce the harmful impacts of environmental stress and enhance crop resistance through multiple processes including improvement of mineral solubilization, phytohormone synthesis, leaf area raising, nutrient absorption, enhanced antioxidant enzyme activity, and soluble protein and chlorophyll concentration [241]. Direct demonstration for such processes derives from the observation that Pseudomonas sp. acdS mutants UW4 (ACC deaminase minus) lost the capacity to stimulate canola root extension during gnotobiotic growth [242], and that canola plants inoculated with the mutant are not able to develop under salinity [243].

Salt tolerant PGPBs producing ACC deaminase have impacts on many biochemical characteristics of plant cells, including production of biocompatible solutes, membrane stability, and the synthesis of photosynthetic pigments during salinity stress [244]. For instance, Jaemsaeng et al. [159] demonstrated that the strain Streptomyces sp. GMKU 336 developing ACC deaminase might improve rice development and salt tolerance by reducing ethylene concentration, scavenging ROS, and preserving ion homeostasis. Biomass and root length of maize plants grown under saline conditions increase in plants inoculated with P. fluorescens possessing ACC deaminase [242]. During abiotic stress, rhizobacteria endowed with ACC deaminase activity may ameliorate plant development by controlling ethylene production [245]. Enhanced ethylene synthesis due to exogenous use of 1-aminocyclopropane-1-carboxylic acid (ACC) 
or salinity may reduce the root development [246], and subsequently increase plant performance. Similarly, supplementation of legume crops with ACC deaminase-synthesizing rhizobia isolated from saline soils boosted nodule construction [247]. The halophilic bacteria Microbacterium sp., isolated from rhizosphere of rice, is another strain that revealed ACC deaminase function [248].

\subsubsection{Induced Systemic Resistance}

Induced systemic resistance (ISR) is the increased protective ability produced by a plant towards a large range of plant pathogens following root microbial colonization $[249,250]$. Besides jasmonate and ethylene, other microbial substances like $\mathrm{O}$-antigenic side chain of the microbial outer membrane protein lipopolysaccharide, pyoverdine, flagellar proteins, $\beta$-glucans, chitin, salicylic acid, and cyclic lipopeptide surfactants have all been identified to operate as signals for the stimulation of systemic tolerance [1]. On the other hand, plants establish tolerance in reaction to pathogen invasion, insect attack, colonization by microorganisms or after processes, but this mediated condition is reflected by the activation of "dormant" immune responses reflected in reaction to external interactions of insects, pathogens, and other invaders [251]. For example, bacteria belonging to taxa such as Bacillus and Pseudomonas sp. have been recognized to stimulate tolerance to pathogenic fungi and bacteria [252]. Plant inoculation with Serratia marcescens strain CDP-13 diminished the intensity of the infection caused Fusarium monaliformiae and Fusarium graminearum, which demonstrated its potential to generate induced systemic resistance in target plants of wheat (Triticum aestivum L.) during salt stress (150-200 mM) [233].

\subsubsection{Ethylene}

Plants, against various stress factors [253], produce ethylene. Ethylene ensures a fundamental function in plant development in a plethora of ways. Ethylene is associated with seed germination, root development (beginning and extension repression), leaf abscission, inactivation of mycorrhiza and plant relationship, and fruit ripening [254]. Ethylene additionally serves as a signal transducer for the detection of salt stress [255]. Accumulation of ethylene in reaction to abiotic stress prevents root development and, eventually, plant growth [256]. Salinity-induced ethylene accumulation caused by high production of 1-aminocyclopropane-1-carboxylic acid (ACC) hinders rice plant growth and development. Nevertheless, ACC deaminase may alleviate salt stress and high ethylene production in rice cultivars under salinity stress [257]. Another crucial enzyme in ethylene biosynthesis is ACC-oxidase (ACO). Maize plants under salt stress have demonstrated enhanced ACO activity as compared to plants under normal condition. Application of PGPR resulted in a significant reduction in ACO activity; Bacillus safensis NBRI 12 M-treated maize plants have exhibited maximum reduction which is consistent with the low ethylene production under salt stress [258].

\section{PGPB Inoculants under Salinity Can Reduce Chemical Fertilization}

While the production of genetically engineered and salt-tolerant varieties, resource management methods, synthetic fertilizers, etc., are cost-intensive and have damaging consequences on humans and the environment, the use of PGPB seems to be a viable option [158-259]. Recently, the use of advantageous halophilic microbes has generated interest in sustainable and environmentally friendly farming [14], with the consequent increase in the exploitation and utilization of microbial fertilizers worldwide [260]. In particular, these microorganisms have multiple characteristics of plant development and these effective and potential microorganisms can be used as biofertilizers to improve soil health and crop productivity for sustainable farming [260]. It is estimated that the market share of biofertilizers will achieve USD 1.66 billion by 2022 and will rise to a CAGR (compound annual growth rate) of $13.2 \%$ in $2015-2022$ [261].

Several methods have been used to mitigate the impact of soil salinity on crops: the application of plant growth regulators, the selection of salt resistant cultivars, and the treatment of seeds with halophilic rhizobacteria [262]. The use of biofertilizers can also minimize the impact of salinity on crops. A biofertilizer may be characterized as a formulated commodity incorporating one or more microbes 
that improve plant nutrient capacity (and increase and productivity) both by replacement soil nutrients, rendering plant nutrients most available, and/or enhancing plant nutrient accessibility [5]. Many other innovations have been involved in increasing salt resistance in plant cultures, along with PGPB to alleviation of salinity stress. Such chemicals' use could be decreased/substituted by P-solubilizing, nitrogen-fixing, and K-solubilizing/mobilizing microorganisms (NPK) as biofertilizer environmentally friendly advancements [8]. The use of microbes in wheat and maize may minimize salt stress effects by about $50 \%$ [263]. The most effective solution to improve productivity and yield in salinity-impacted regions is predominantly the use of PGPB as inoculums in cultivation to mitigate salt stress. The great opportunity for investigations concerning crop salinity resistance is actually their capacity to be associated with PGPR [264].

\section{Conclusions}

Salinity is a great threat for agriculture by affecting soil, microorganisms, and plants throughout their development cycle, from germination to maturation. Moreover, salinity may influence different vital processes in plant such as photosynthesis, respiration, senescence, and flowering. Particularly, PGPBs show a great capacity for saline stress alleviation mainly because of their resistance, adaptability, and a huge variability of the mechanisms involved in this process. Several investigations and experiments have demonstrated that the PGPB is a potential alternative to chemical fertilizers, biopesticides, and bioremediators under salt stress. Additionally, the most important PGPBs progress to date was the elucidation of various molecular mechanisms involved in plant microorganism interactions, in different plants and their utilization efficiently as bioinoculants in soil salinity mitigation. Recently, a genotypic approach was adopted through the characterization of different salinity tolerance implicated genes.

In the future, we recommend using soil autochthonous microorganisms that were mentioned in a number of investigations to be more efficient in soil salinity bioremediation. That may remediate the problem of survival and durability of PGPB in soil. Additionally, synergetic effects through the combination of hemophilic plants (phytoremediation) to PGPB seem to be very promising in soil salinity mitigation. The challenge of host specificity can be determined by adopting a multidisciplinary approach like proteomic, meta-transcriptomic, meta-genomic, etc. For reducing commercial formulation cost, traditional fermentation techniques can be used in small farming systems. Low price fermentation substrates like compost may be developed.

Author Contributions: The first author S.M. wrote the draft; the second author E.-h.N. completed the draft until the final manuscript. The third C.C. revised it and added some necessary details. All authors have read and agreed to the published version of the manuscript.

Funding: This study was financially supported by Portuguese funds through Républica Portuguesa and Fundação para a Ciência e a Tecnologia (FCT) through the projects UIDB/00329/2020 and PTDC/ASP-HOR/29187/2017.

Acknowledgments: We thank Abbaci Hocine (University of Bejaia-Algeria) for his precious help in figure preparation and correction.

Conflicts of Interest: No conflict of interest to declare.

\section{References}

1. Glick, B.R. Plant growth-promoting bacteria: Mechanisms and applications. Scientifica 2012, 2012, 1-15. [CrossRef]

2. Chandra, D.; Srivastava, R.; Gupta, V.V.; Franco, C.M.; Sharma, A.K. Evaluation of ACC-deaminase-producing rhizobacteria to alleviate water-stress impacts in wheat (Triticum aestivum L.) plants. Can. J. Microbiol. 2019, 65, 387-403. [CrossRef] [PubMed]

3. Grime, J.P. Evidence for the existence of three primary strategies in plants and its relevance to ecological and evolutionary theory. Am. Nat. 1977, 111,169-1194. [CrossRef]

4. Kumar, A.; Verma, J.P. Does plant-microbe interaction confer stress tolerance in plants: A review? Microbiol. Res. 2018, 207, 41-52. [CrossRef]

5. Machado, R.M.A.; Serralheiro, R.P. Soil salinity: Effect on vegetable crop growth. Management practices to prevent and mitigate soil salinization. Horticulturae 2017, 3, 30. [CrossRef] 
6. Pimentel, D.; Berger, B.; Filiberto, D.; Newton, M.; Wolfe, B.; Karabinakis, E.; Clark, S.; Poon, E.; Abbett, E.; Nandaopal, S. Water Resources: Agricultural and Environmental Issues. BioScience 2004, 54, 909-918. [CrossRef]

7. Numan, M.; Bashir, S.; Khan, Y.; Mumtaz, R.; Shinwari, Z.K.; Khan, A.L.; Khan, A.; Ahmed, A.H. Plant growth promoting bacteria as an alternative strategy for salt tolerance in plants: A review. Microbiol. Res. 2018, 209, 21-32. [CrossRef]

8. Yadav, A.N.; Saxena, A.K. Biodiversity and biotechnological applications of halophilic microbes for sustainable agriculture. J. Appl. Biol. Biotechnol. 2018, 6, 48-55. [CrossRef]

9. Munns, R. Genes and salt tolerance: Bringing them together. New Phytol. 2005, 167, 645-663. [CrossRef]

10. Jamil, A.; Riaz, S.; Ashraf, M.; Foolad, M.R. Gene expression profiling of plants under salt stress. Crit. Rev. Plant Sci. 2011, 30, 435-458. [CrossRef]

11. Arora, S. Halotolerant Microbes for Amelioration of Salt-Affected Soils for Sustainable Agriculture. In Phyto-Microbiome in Stress Regulation; Kumar, M., Kumar, V., Prasad, R., Eds.; Springer: Singapore, 2020; pp. 323-343.

12. Zhang, K.; Shi, Y.; Cui, X.; Yue, P.; Li, K.; Liu, X.; Tripathi, B.M.; Chu, H. Salinity is a key determinant for soil microbial communities in a desert ecosystem. MSystems 2019, 4, 1-11. [CrossRef] [PubMed]

13. Chu, T.N.; Tran, B.T.H.; Hoang, M.T.T. Plant growth-promoting rhizobacterium Pseudomonas PS01 induces salt tolerance in Arabidopsis thaliana. BMC Res. Notes 2019, 12, 1-7. [CrossRef] [PubMed]

14. Paul, D.; Lade, H. Plant-growth-promoting rhizobacteria to improve crop growth in saline soils: A review. Agron. Sustain. Dev. 2014, 34, 737-752. [CrossRef]

15. Vessey, J.K. Plant growth promoting rhizobacteria as biofertilizers. Plant Soil 2003, 255, 571-586. [CrossRef]

16. Souza, R.D.; Ambrosini, A.; Passaglia, L.M. Plant growth-promoting bacteria as inoculants in agricultural soils. Genet. Mol. Biol. 2015, 38, 401-419. [CrossRef]

17. Bakka, K.; Challabathula, D. Amelioration of Salt Stress Tolerance in Plants by Plant Growth-Promoting Rhizobacteria: Insights from “Omics" Approaches. In Plant Microbe Symbiosis; Varma, A., Tripathi, S., Prasad, R., Eds.; Springer: Cham, Switzerland, 2020; pp. 303-330.

18. El-Akhdar, I.; Elsakhawy, T.; Abo-Koura, H.A. Alleviation of Salt Stress on Wheat (Triticum aestivum L.) by Plant Growth Promoting Bacteria strains Bacillus halotolerans MSR-H4 and Lelliottia amnigena MSR-M49. J. Adv. Appl. Microbiol. 2020, 20, 44-58. [CrossRef]

19. Obledo, E.N.; Barraga'n-Barraga'n, L.B.; Gutie'rrez-Gonza'lez, P.; Ramı'rez-Herna'ndez, B.C.; Ramı'rez, J.J.; Rodri'guez-Garay, B. Increased photosyntethic efficiency generated by fungal symbiosis in Agave victoria-reginae. Plant Cell Tissue Organ Cult. 2003, 74, 237-241. [CrossRef]

20. Lynch, J.M. The Rhizosphere; Wiley-Interscience: Chichester, UK, 1990; p. 4.

21. Schoenborn, L.; Yates, P.S.; Grinton, B.E.; Hugenholtz, P.; Janssen, P.H. Liquid serial dilution is inferior to solid media for isolation of cultures representative of the phylum-level diversity of soil bacteria. Appl. Environ. Environ. Microbiol. 2004, 70, 4363-4366. [CrossRef]

22. Egamberdieva, D.; Wirth, S.; Bellingrath-Kimura, S.D.; Mishra, J.; Arora, N.K. Salt-Tolerant Plant Growth Promoting Rhizobacteria for Enhancing Crop Productivity of Saline Soils. Front. Microbiol. 2019, 10, 1-18. [CrossRef]

23. Whipps, J.M. Microbial interactions and biocontrol in the rhizosphere. J. Exp. Bot. 2001, 52, 487-511. [CrossRef]

24. Ilangumaran, G.; Smith, D.L. Plant Growth Promoting Rhizobacteria in Amelioration of Salinity Stress: A Systems Biology Perspective. Front. Plant Sci. 2017, 8, 1-14. [CrossRef] [PubMed]

25. Ruppel, S.; Franken, P.; Witzel, K. Properties of the halophyte microbiome and their implications for plant salt tolerance. Funct. Plant Biol. 2013, 40, 940-951. [CrossRef] [PubMed]

26. Kadmiri, I.M.; Chaouqui, L.; Azaroual, S.E.; Sijilmassi, B.; Yaakoubi, K.; Wahby, I. Phosphate-solubilizing and auxin-producing rhizobacteria promote plant growth under saline conditions. Arab. J. Sci. Eng. 2018, 43, 3403-3415. [CrossRef]

27. Ismael, R.R.; Ahmad, E.S.; Abdel-Fattah, M.; Omar, M.N.; Azzam, C.R.; Zahran, H.H. Effect of plant growth-promoting rhizobacteria on growth and symbiotic nitrogen fixation of Vicia faba plants under salt stress. Plant Sci. J. 2018, 7, 1-19.

28. Braud, A.; Jézéquel, K.; Bazot, S.; Lebeau, T. Enhanced phytoextraction of an agricultural Cr-and Pb-contaminated soil by bioaugmentation with siderophore-producing bacteria. Chemosphere 2009, 74, 280-286. [CrossRef]

29. Kumar, A.; Verma, J.P. The role of microbes to improve crop productivity and soil health. In Ecological Wisdom Inspired Restoration Engineering; Achal, V., Mukherjee, A., Eds.; Springer: Singapore, 2019; pp. 249-265. 
30. Kumar, A.; Singh, S.; Gaurav, A.K.; Srivastava, S.; Verma, J.P. Plant Growth-Promoting Bacteria: Biological Tools for the Mitigation of Salinity Stress in Plants. Front. Microbiol. 2020, 11, 1216. [CrossRef]

31. Kamran, M.; Parveen, A.; Ahmar, S.; Malik, Z.; Hussain, S.; Chattha, M.S.; Saleem, M.H.; Adil, M.; Heidari, P.; Chen, J.T. An overview of hazardous impacts of soil salinity in crops, tolerance mechanisms, and amelioration through selenium supplementation. Int. J. Mol. Sci. 2020, 21, 148. [CrossRef]

32. Munns, R.; Gilliham, M. Salinity tolerance of crops-What is the cost? New Phytol. 2015, 208, 668-673. [CrossRef]

33. Volkmar, K.M.; Hu, Y.; Steppuhn, H. Physiological responses of plants to salinity: A review. Can. J. Plant Sci. 1998, 78, 19-27. [CrossRef]

34. De Souza Silva, C.M.M.; Fay, E.F. Effect of salinity on soil microorganisms. Soil Health Land Use Manag. 2012, 10, 177-198. [CrossRef]

35. Zhang, H.X.; Irving, L.J.; McGill, C.; Matthew, C.; Zhou, D.; Kemp, P. The effects of salinity and osmotic stress on barley germination rate: Sodium as an osmotic regulator. Ann. Bot. 2010, 106, 1027-1035. [CrossRef] [PubMed]

36. Keating, B.; Fisher, M. Comparative tolerance of tropical grain legumes to salinity. Aust. J. Agric. Res. 1985, 36, 373-383. [CrossRef]

37. Abbaszadeh, F.; Rameeh, V.; Charati, A. Salinity Stress Indices of Seed Yield and Nutrient Compositions in Rapeseed. Int. J. Biol. 2012, 4, 154-162. [CrossRef]

38. Ghanem, M.E.; van Elteren, J.; Albacete, A.; Quinet, M.; Martínez-Andújar, C.; Kinet, J.M.; Pérez-Alfocea, F.; Lutts, S. Impact of salinity on early reproductive physiology of tomato (Solanum lycopersicum) in relation to a heterogeneous distribution of toxic ions in flower organs. Funct. Plant Biol. 2009, 36, 125-136. [CrossRef] [PubMed]

39. Hussain, S.; Shaukat, M.; Ashraf, M.; Zhu, C.; Jin, Q.; Zhang, J. Salinity stress in arid and semi-arid climates: Effects and management in field crops. In Climate Change and Agriculture; Hussain, S., Ed.; IntechOpen: London, UK, 2019; pp. 1-26.

40. Pitman, M.G.; Läuchli, A. Global impact of salinity and agricultural ecosystems. In Salinity: Environment-Plants-Molecules; Läuchli, A., Lüttge, U., Eds.; Springer: Dordrecht, The Netherlands, 2002; pp. 3-20.

41. Essington, M.E. Soil and Water Chemistry-An Integrative Approach; CRC Press: Boca Raton, FL, USA, $2004 ;$ p. 500.

42. Zhang, H.H.; Xu, N.; Wu, X.; Wang, J.; Ma, S.; Li, X.; Sun, G. Effects of four types of sodium salt stress on plant growth and photosynthetic apparatus in sorghum leaves. J. Plant Interact. 2018, 13, 506-513. [CrossRef]

43. Negrão, S.; Schmöckel, S.M.; Tester, M. Evaluating physiological responses of plants to salinity stress. Ann. Bot. 2017, 119, 1-11. [CrossRef]

44. Maggio, A.; Raimondi, G.; Martino, A.; De Pascale, S. Salt stress response in tomato beyond the salinity tolerance threshold. Environ. Exp. Bot. 2007, 59, 276-282. [CrossRef]

45. Gupta, B.; Huang, B. Mechanism of salinity tolerance in plants: Physiological, biochemical, and molecular characterization. Int. J. Genom. 2014, 2014, 1-18. [CrossRef]

46. Wu, G.Q.; Jiao, Q.; Shui, Q.Z. Effect of salinity on seed germination, seedling growth, and inorganic and organic solutes accumulation in sunflower (Helianthus annuus L.). Plant Soil Environ. 2015, 61, 220-226. [CrossRef]

47. Farkhondeh, R.; Nabizadeh, E.; Jalilnezhad, N. Effect of salinity stress on proline content, membrane stability and water relations in two sugar beet cultivars. Int. J. Agric. Sci. 2012, 2, 385-392.

48. Cassaniti, C.; Romano, D.; Hop, M.E.C.M.; Flowers, T.J. Growing floricultural crops with brackish water. Environ. Exp. Bot. 2013, 92, 165-175. [CrossRef]

49. Parihar, P.; Singh, S.; Singh, R.; Singh, V.P.; Prasad, S.M. Effect of salinity stress on plants and its tolerance strategies: A review. Environ. Sci. Pollut. Res. 2015, 22, 4056-4075. [CrossRef] [PubMed]

50. Bensidhoum, L.; Nabti, E.H. Plant Growth-Promoting Bacteria for Improving Crops under Saline Conditions. In Microorganisms in Saline Environments: Strategies and Functions; Giri, B., Varma, A., Eds.; Springer: Cham, Switzerland, 2019; pp. 329-352.

51. Parida, A.K.; Das, A.B. Salt tolerance and salinity effects on plants: A review. Ecotoxicol. Environ. Saf. 2005, 60, 324-349. [CrossRef] [PubMed]

52. Parvaiz, A.; Satyawati, S. Salt stress and phyto-biochemical responses of plants-A review. Plant Soil Environ. 2008, 54, 89-99. [CrossRef]

53. Munns, R.; Husain, S.; Rivelli, A.R.; Richard, A.J.; Condon, A.G.; Megan, P.L.; Evans, S.L.; Schachtman, D.P.; Hare, R.A. Avenues for increasing salt tolerance of crops, and the role of physiologically based selection traits. Plant Soil 2002, 247, 93-105. [CrossRef] 
54. Ashraf, M.; Hasnain, S.; Berge, O.; Mahmood, T. Inoculating wheat seedling with exopolysaccharide-producing bacteria restricts sodium uptake and stimulates plant growth under salt stress. Biol. Fertil. Soils 2004, 40, 152-157. [CrossRef]

55. Radić, S.; Štefanić, P.P.; Lepeduš, H.; Roje, V.; Pevalek-Kozlina, B. Salt tolerance of Centaurea ragusina L. is associated with efficient osmotic adjustment and increased antioxidative capacity. Environ. Exp. Bot. 2013, 87, 39-48. [CrossRef]

56. Liu, S.; Hao, H.; Lu, X.; Zhao, X.; Wang, Y.; Zhang, Y.; Xie, Z.; Wang, R. Transcriptome profiling ofgenes involved in induced systemic salt tolerance conferred by Bacillus amyloliquefaciens FZB42 in Arabidopsis thaliana. Sci. Rep. 2017, 7, 1-3. [CrossRef]

57. Donohue, K. Seeds and seasons: Interpreting germination timing in the field. Seed Sci. Res. 2005, 15, 175-187. [CrossRef]

58. Živković, S.; Dević, M.; Filipović, B.; Giba, Z.; Grubišić, D. Effect of $\mathrm{NaCl}$ on seed germination in some Centaurium Hill. species (Gentianaceae). Arch. Biol. Sci. 2007, 59, 227-231. [CrossRef]

59. Gulzar, S.; Khan, M.A.; Ungar, I.A. Salt tolerance of a coastal salt marsh grass. Commun. Soil Sci. Plant Anal. 2003, 34, 2595-2605. [CrossRef]

60. Giménez Luque, E.; Delgado Fernández, I.C.; Gómez Mercado, F. Effect of salinity and temperature on seed germination in Limonium cossonianum. Botany 2013, 91, 12-16. [CrossRef]

61. Bojović, B.; Đelić, G.; Topuzović, M.; Stanković, M. Effects of $\mathrm{NaCl}$ on seed germination in some species from families Brassicaceae and Solanaceae. Kragujev. J. Sci. 2010, 32, 83-87.

62. Shokohifard, G.; Sakagami, K.; Hamada, R.; Matsumoto, S. Effect of amending materials on growth of radish plant in salinized soil. J. Plant Nutr. 1989, 12, 1195-1214. [CrossRef]

63. Rahman, M.; Soomro, U.A.; Haq, M.Z.U.; Gul, S.H. Effects of $\mathrm{NaCl}$ salinity on wheat (Triticum aestivum L.) cultivars. World J. Agric. Res. 2008, 4, 398-403.

64. Al-swedi, F.G.; Alshamari, M.; Al_Zaidi, I.H.M.; Rihan, H.Z. Impact of Salinity Stress on Seed Germination in Lettuce (Lactuca Sativa). J. Res. Lepid. 2020, 51, 374-385. [CrossRef]

65. Bagwasi, G.; Agenbag, G.A.; Swanepoel, P.A. Effect of salinity on the germination of wheat and barley in South Africa. Crop. Forage Turfgrass Manag. 2020. [CrossRef]

66. Bhatnagar-Mathur, P.; Vadez, V.; Sharma, K.K. Transgenic approaches for abiotic stress tolerance in plants: Retrospect and prospects. Plant Cell Rep. 2008, 27, 411-424. [CrossRef]

67. Hniličková, H.; Hnilička, F.; Martinkova, J.; Kraus, K. Effects of salt stress on water status, photosynthesis and chlorophyll fluorescence of rocket. Plant Soil Environ. 2017, 63, 362-367. [CrossRef]

68. Aquino, A.J.S.; Lacerda, C.F.; Bezerra, M.A.; Gomes-Filho, E.; Costa, R.N.T. Crescimento, partição de matéria seca e retenção de $\mathrm{Na}^{+}$e Cl- em dois genótipos de sorgo irrigados com águas salinas. Rev. Bras. Ciênc. Solo 2007, 31, 961-971. [CrossRef]

69. Chaves, M.M.; Flexas, J.; Pinheiro, C. Photosynthesis under drought and salt stress: Regulation mechanisms from whole plant to cell. Ann. Bot. 2009, 103, 551-560. [CrossRef] [PubMed]

70. Qiu, D.L.; Lin, P.; Guo, S.Z. Effects of salinity on leaf characteristics and CO2/H2O exchange of Kandelia candel (L.) Druce seedlings. J. For. Sci. 2007, 53, 13-19. [CrossRef]

71. Jamil, M.; Rehman, S.; Lee, K.J.; Kim, J.M.; Kim, H.; Rha, E.S. Salinity reduced growth PS2 photochemistry and chlorophyll content in radish. Sci. Agric. 2007, 64, 111-118. [CrossRef]

72. Desingh, R.; Kanagaraj, G. Effect of salinity stress on photosynthetic enzymes of two sesame (Sesamum indicum L.) Varieties. Plant Arch. 2020, 20, 16-20.

73. Jacoby, R.P.; Millar, A.H.; Taylor, N.L. Investigating the role of respiration in plant salinity tolerance by analyzing mitochondrial proteomes from wheat and a salinity-tolerant Amphiploid (wheat $x$ Lophopyrum elongatum). J. Proteome Res. 2013, 12, 4807-4829. [CrossRef]

74. Zapata, P.J.; Serrano, M.; Pretel, M.T.; Amorós, A.; Botella, M.A. Polyamines and ethylene changes during germination of different plant species under salinity. Plant Sci. 2004, 167, 781-788. [CrossRef]

75. Schwarz, M.; Gale, J. Maintenance respiration and earbon balance of plants at low levels of sodium chloride salinity. J. Exp. Bot. 1981, 32, 933-941. [CrossRef]

76. Yeo, A.R. Salinity resistance: Physiologies and prices. Physiol. Plant. 1983, 58, 214-222. [CrossRef]

77. Epron, D.; Toussaint, M.L.; Badot, P.M. Effects of sodium chloride salinity on root growth and respiration in oak seedlings. Ann. For. Sci. 1999, 56, 41-47. [CrossRef] 
78. Moud, A.M.; Maghsoudi, K. Salt stress effects on respiration and growth of germinated seeds of different wheat (Triticum aestivum L.) cultivars. World J. Agric. Sci. 2008, 4, 351-358.

79. Che-Othman, M.H.; Jacoby, R.P.; Millar, A.H.; Taylor, N.L. Wheat mitochondrial respiration shifts from the tricarboxylic acid cycle to the GABA shunt under salt stress. New Phytol. 2020, 225, 1166-1180. [CrossRef] [PubMed]

80. Ghanem, M.E.; Albacete, A.; Martínez-Andújar, C.; Acosta, M.; Romero-Aranda, R.; Dodd, I.C.; Lutts, S.; Pérez-Alfocea, F. Hormonal changes during salinity-induced leaf senescence in tomato (Solanum lycopersicum L.). J. Exp. Bot. 2008, 59, 3039-3050. [CrossRef] [PubMed]

81. Cramer, G.R.; Nowak, R.S. Supplemental manganese improves the relative growth, net assimilation and photosynthetic rates of salt-stressed barley. Physiol. Plant. 1992, 84, 600-605. [CrossRef]

82. Lim, P.O.; Kim, H.J.; Nam, H.G. Leaf senescence. Annu. Rev. Plant Biol. 2007, 58, 115-136. [CrossRef]

83. Shabala, S. Salinity and programmed cell death: Unraveling mechanisms for ion specific signaling. J. Exp. Bot. 2009, 60, 709-712. [CrossRef]

84. Tester, M.; Davenport, R.J. Na ${ }^{+}$transport and $\mathrm{Na}^{+}$tolerance in higher plants. Ann. Bot. 2003, 91, 503-527. [CrossRef] [PubMed]

85. Lee, R.H.; Wang, C.H.; Huang, L.T.; Chen, S.C.G. Leaf senescence in rice plants: Cloning and characterization of senescence up-regulated genes. J. Exp. Bot. 2001, 52, 1117-1121. [CrossRef]

86. Li, Y.; Beisson, F.; Pollard, M.; Ohlrogge, J. Oil content of Arabidopsis seeds: The influence of seed anatomy, light and plant-to-plant variation. Phytochemistry 2006, 67, 904-915. [CrossRef]

87. Yuenyong, W.; Sirikantaramas, S.; Qu, L.J.; Buaboocha, T. Isocitrate lyase plays important roles in plant salt tolerance. BMC Plant Biol. 2019, 19, 1-14. [CrossRef]

88. Chrysargyris, A.; Tzionis, A.; Xylia, P.; Tzortzakis, N. Effects of salinity on tagetes growth, physiology, and shelf life of edible flowers stored in passive modified atmosphere packaging or treated with ethanol. Front. Plant Sci. 2018, 9, 1-13. [CrossRef]

89. Zapryanova, N.; Atanassova, B. Effects of salt stress on growth and flowering of ornamental annual species. Biotechnol. Biotechnol. Equip. 2009, 23, 177-179. [CrossRef]

90. Bybordi, A. Effects of salinity on yield and component characters in canola (Brassica napus L.) cultivars. Not. Sci. Biol. 2010, 2, 81-83. [CrossRef]

91. Mass, E.V.; Poss, J.A. Salt sensitivity of Maintenance respiration was estimated to be about wheat at various growth stages. Irrig. Sci. 1989, 10, 29-40.

92. Flores, H. Changes in polyamine metabolism in response to abiotic stress. In Biochemistry and Physiology of Polyamines in Plants; Slocum, I.R., Flores, H., Eds.; CRC Press: Boca Raton, FL, USA, 1991; pp. $214-225$.

93. Limami, M.A.; Leach, F.; Brugiere, N.; Aziz, A.; Martin, T.J.; Malmberg, R.L.; Hirel, B.; Tepfer, D. Altered Polyamine Metabolism and Stress-Induced Proline Accumulation in Genetically Manipulated Tobacco. In Proceedings of the Dahlia Greidinger International Symposium on Nutrient Management under Salinity and Water Stress, Haifa, Palestine, 1-4 March 1999.

94. Salem, N.; Msaada, K.; Dhifi, W.; Limam, F.; Marzouk, B. Effect of salinity on plant growth and biological activities of Carthamus tinctorius L. extracts at two flowering stages. Acta Physiol. Plant 2014, 36, $433-445$. [CrossRef]

95. Singh, N.K.; La Rosa, P.C.; Handa, A.K.; Hasegawa, P.M.; Bressan, R.A. Hormonal regulation of protein synthesis associated with salt tolerance in plant cells. Proc. Natl. Acad. Sci. USA 1987, 84, 739-743. [CrossRef]

96. Blaha, G.; Stelzl, U.; Spahn, C.M.T.; Agrawal, R.K.; Frank, J.; Nierhaus, K.H. Preparation of functional ribosomal complexes and effect of buffer conditions on tRNA positions observed by cryoelectron microscopy. Methods Enzymol. 2000, 317, 292-309. [CrossRef]

97. Maaroufi-Dguimi, H.; Debouba, M.; Gaufichon, L.; Clément, G.; Gouia, H.; Hajjaji, A.; Susuki, A. An Arabidopsis mutant disrupted in ASN2 encoding asparagine synthetase 2 exhibits low salt stress tolerance. Plant Physiol. Biochem. 2011, 49, 623-628. [CrossRef]

98. Silveira, J.A.G.; Melo, A.R.B.; Viégas, R.A.; Oliveira, J.T.A. Salinity-induced effects on nitrogen assimilation related to growth in cowpea plants. Environ. Exp. Bot. 2001, 46, 171-179. [CrossRef]

99. Qu, C.; Liu, C.; Ze, Y.; Gong, X.; Hong, M.; Wang, L.; Hong, F. Inhibition of nitrogen and photosynthetic carbon assimilation of maize seedlings by exposure to a combination of salt stress and potassium-deficient stress. Biol. Trace Elem. Res. 2011, 144, 1159-1174. [CrossRef] 
100. Queiroz, H.M.; Sodek, L.; Haddad, C.R.B. Effect of salt on the growth and metabolism of Glycine max. Braz. Arch. Biol. Technol. 2012, 55, 809-817. [CrossRef]

101. Arefian, M.; Vessal, S.; Malekzadeh-Shafaroudi, S.; Siddique, K.H.; Bagheri, A. Comparative proteomics and gene expression analyses revealed responsive proteins and mechanisms for salt tolerance in chickpea genotypes. BMC Plant Biol. 2019, 19, 1-26. [CrossRef] [PubMed]

102. Yu, Y.; Kou, M.; Gao, Z.; Liu, Y.; Xuan, Y.; Tang, Z.; Cao, Q.; Li, Z.; Sun, J. Involvement of phosphatidyl serine and triacylglycerol in the response of sweet potato leaves to salt stress. Front. Plant Sci. 2019, 10, 1-27. [CrossRef] [PubMed]

103. Bybordi, A. Effects of $\mathrm{NaCl}$ salinity levels on lipids and proteins of canola (Brassica napus L.) cultivars. Rom. Agric. Res. 2011, 28, 197-206.

104. Khalid, A.K.; Shedeed, M.R. Influence of kinetin on growth and biochemical accumulation in Nigella sativa plants grow under salinity stress conditions. Thai J. Agric. Sci. 2014, 47, 195-203.

105. Mansour, M.M.F.; Salama, K.H.A.; Ali, F.Z.M.; Abou Hadid, A.F. Cell and plant responses to NaCl in Zea mays L. cultivars differing in salt tolerance. Gen. Appl. Plant Physiol. 2005, 31, $29-41$.

106. Elkahoui, S.; Hernández, J.A.; Abdelly, C.; Ghrir, R.; Limam, F. Effects of salt on lipid peroxidation and antioxidant enzyme activities of Catharanthus roseus suspension cells. Plant Sci. 2005, 168, 607-613. [CrossRef]

107. Watanabe, Y.; Takakuwa, M. Change of lipid composition of Zygosaccharomyces rouxii after transfer to high sodium chloride culture medium. J. Ferment. Technol. 1987, 65, 365-369. [CrossRef]

108. Sui, N.; Wang, Y.; Liu, S.; Yang, Z.; Wang, F.; Wan, S. Transcriptomic and physiological evidence for the relationship between unsaturated fatty acid and salt stress in peanut. Front. Plant Sci. 2018, 9, 1-12. [CrossRef]

109. Barros, J.A.; Siqueira, J.A.; Cavalcanti, J.H.; Araújo, W.L.; Avin-Wittenberg, T. Multifaceted Roles of Plant Autophagy in Lipid and Energy Metabolism. Trends Plant Sci. 2020. [CrossRef]

110. Glass, D.J. US and International Markets for Phytoremediation, 1999-2000; Glass Associates, Inc.: Needham, MA, USA, 1999.

111. Schirawski, J.; Perlin, M.H. Plant-microbe interaction 2017-the good, the bad and the diverse. Int. J. Mol. Sci. 2018, 19, 1374. [CrossRef]

112. Frankenberger, W.T.; Bingham, F.T. Influence of salinity on soil enzyme activities. Soil Sci. Soc. Am. J. 1982, 46, 1173-1177. [CrossRef]

113. Jesus, J.M.; Danko, A.S.; Fiúza, A.; Borges, M.T. Phytoremediation of salt-affected soils: A review of processes, applicability, and the impact of climate change. Environ. Sci. Pollut. Res. 2015, 22, 6511-6525. [CrossRef] [PubMed]

114. Fazal, A.; Bano, A. Role of plant growth-promoting rhizobacteria (PGPR), biochar, and chemical fertilizer under salinity stress. Commun. Soil Sci. Plant Anal. 2016, 47, 1985-1993. [CrossRef]

115. Srivastava, P.; Wu, Q.S.; Giri, B. Salinity: An Overview. In Microorganisms in Saline Environments: Strategies and Functions; Giri, B., Varma, A., Eds.; Springer: Cham, Switzerland, 2019; Volume 56, pp. 3-18.

116. Diacono, M.; Montemurro, F. Effectiveness of organic wastes as fertilizers and amendments in salt-affected soils. Agriculture 2015, 5, 221-230. [CrossRef]

117. Sadegh-Zadeh, F.; Parichehreh, M.; Jalili, B.; Bahmanyar, M.A. Rehabilitation of calcareous saline-sodic soil by means of biochars and acidified biochars. Land Degrad. Dev. 2018, 29, 3262-3271. [CrossRef]

118. Saifullah, D.S.; Naeem, A.; Rengel, Z.; Naidu, R. Biochar application for the remediation of salt-affected soils: Challenges and opportunities. Sci. Total Environ. 2018, 625, 320-335. [CrossRef]

119. Carillo, P.; Annunziata, M.G.; Pontecorvo, G.; Fuggi, A.; Woodrow, P. Salinity stress and salt tolerance. In Abiotic Stress in Plants-Mechanisms and Adaptations; Shanker, A., Venkateswarlu, B., Eds.; InTechOpen: Rijeka, Croatia, 2011; Volume 1, pp. 21-38.

120. Carmen, B.; Roberto, D. Soil bacteria support and protect plants against abiotic stresses. In Abiotic Stress in Plants: Mechanisms and Adaptations; Shanker, A.K., Venkateswarlu, B., Eds.; InTech: Rijeka, Croatia, 2011; pp. 143-170.

121. Usman, A.R. Influence of $\mathrm{NaCl}$-induced salinity and $\mathrm{Cd}$ toxicity on respiration activity and $\mathrm{Cd}$ availability to barley plants in farmyard manure-amended soil. Appl. Environ. Soil Sci. 2015, 2015, 1-8. [CrossRef]

122. Elmajdoub, B.; Marschner, P. Response of microbial activity and biomass to soil salinity when supplied with glucose and cellulose. J. Soil Sci. Plant Nutr. 2015, 15, 816-832. [CrossRef]

123. Lodhi, A.; Arshad, M.; Azam, F.; Sajjad, M.H. Changes in mineral and mineralizable N of soil incubated at varying salinity, moisture and temperature regimes. Pak. J. Bot. 2009, 41, 967-980. 
124. Qadir, M.; Schubert, S. Degradation processes and nutrient constraints in sodic soils. Land Degrad. Dev. 2002, 13, 275-294. [CrossRef]

125. Informativo Capebe-06/12/2010-Umpatrimônio Chamado Solo. Available online: http://www.capebe.org.br/ informativo.php?id=355 (accessed on 13 June 2011).

126. Egamberdieva, D.; Renella, G.; Wirth, S.; Islam, R. Secondary salinity effects on soil microbial biomass. Biol. Fertil. Soils 2010, 46, 445-449. [CrossRef]

127. Troxler, T.G.; Ikenaga, M.; Scinto, L.; Boyer, J.N.; Condit, R.; Perez, R.; Gann, G.D.; Childers, D.L. Patterns of Soil bacteria and Canopy Community structure related to tropical peatland development. Wetlands 2012, 32, 769-782. [CrossRef]

128. Pathak, H.; Rao, D. Carbon and nitrogen mineralization from added organic matter in saline and alkaline soils. Soil Biol. Biochem. 1998, 30, 695-702. [CrossRef]

129. Muhammad, S.; Müller, T.; Joergensen, R. Decomposition of pea and maize straw in Pakistani soils along a gradient in salinity. Biol. Fertil. Soils 2006, 43, 93-101. [CrossRef]

130. Zhang, W.W.; Chong, W.A.N.G.; Rui, X.U.E.; Wang, L.J. Effects of salinity on the soil microbial community and soil fertility. J. Integr. Agric. 2019, 18, 1360-1368. [CrossRef]

131. Ibekwe, A.M.; Ors, S.; Ferreira, J.F.; Liu, X.; Suarez, D.L. Seasonal induced changes in spinach rhizosphere microbial community structure with varying salinity and drought. Sci. Total Environ. 2017, 579, 1485-1495. [CrossRef]

132. Borneman, J.; Skroch, P.W.; O’Sullivan, K.M.; Palus, J.A.; Rumjanek, N.G.; Jansen, J.L.; Nienhuis, J.; Triplett, E.W. Molecular microbial diversity of an agricultural soil in Wisconsin. Appl. Environ. Microbiol. 1996, 62, 1935-1943. [CrossRef]

133. Rousk, J.; Elyaagubi, F.K.; Jones, D.L.; Godbold, D.L. Bacterial salt tolerance is unrelated to soil salinity across an arid agro-ecosystem salinity gradient. Soil Biol. Biochem. 2011, 43, 1881-1887. [CrossRef]

134. Tripathi, S.; Kumari, S.; Chakraborty, A.; Gupta, A.; Chakrabarti, K.; Bandyapadhyay, B.K. Microbial biomass and its activities in salt-affected coastal soils. Biol. Fertil. Soils 2006, 42, 273-277. [CrossRef]

135. Nabti, E.; Schmid, M.; Hartmann, A. Application of halotolerant bacteria to restore plant growth under salt stress. In Halophile: Biodiversity and Sustainable Exploitation; Maheshwari, D.K., Saraf, M., Eds.; Springer: Cham, Switzerland, 2015; pp. 235-259.

136. Amato, M.; Ladd, J.N. Application of the ninhydrin-reactive $\mathrm{N}$ assay for microbial biomass in acid soils. Soil Biol. Biochem. 1994, 26, 1109-1115. [CrossRef]

137. Gunde-Cimerman, N.; Zalar, P.; de Hoog, S.; Plemenitas, A. Hypersaline waters in salterns-natural ecological niches for halophilic black yeasts. FEMS Microbiol. Ecol. 2000, 32, 235-240. [CrossRef]

138. Omar, S.A.; Abdel-Sater, M.A.; Khallil, A.M.; Abdalla, M.H. Growth and enzyme activities of fungi and bacteria in soil salinized with sodium chloride. Folia Microbiol. 1994, 39, 23-28. [CrossRef]

139. Juniper, S.; Abbott, L.K. Soil salinity delays germination and limits growth of hyphae from propagules of arbuscular mycorrhizal fungi. Mycorrhiza 2006, 16, 371-379. [CrossRef] [PubMed]

140. Saxena, A.K.; Yadav, A.N.; Rajawat, M.; Kaushik, R.; Kumar, R.; Kumar, M.; Prasanna, R.; Shukla, L. Microbial diversity of extreme regions: An unseen heritage and wealth. Indian J. Plant Genet. Resour. 2016, 29, $246-248$. [CrossRef]

141. Yadav, A.N.; Verma, P.; Kaushik, R.; Dhaliwal, H.S.; Saxena, A.K. Archaea endowed with plant growth promoting attributes. EC Microbiol. 2017, 8, 294-298.

142. Ramadoss, D.; Lakkineni, V.K.; Bose, P.; Ali, S.; Annapurna, K. Mitigation of salt stress in wheat seedlings by halotolerant bacteria isolated from saline habitats. SpringerPlus 2013, 2, 1-7. [CrossRef]

143. Yao, L.; Wu, Z.; Zheng, Y.; Kaleem, I.; Li, C. Growth promotion and protection against salt stress by Pseudomonas putida Rs-198 on cotton. Eur. J. Soil Biol. 2010, 46, 49-54. [CrossRef]

144. Arora, S.; Trivedi, R.; Rao, G.G. Bioremediation of coastal and inland salt affected soils using halophyte plants and halophilic soil microbes. In CSSRI Annual Report 2012-13; CSSRI: Karnal, India, 2013; pp. 94-100.

145. Grover, M.; Ali, S.Z.; Sandhya, V.; Rasul, A.; Venkateswarlu, B. Role of microorganisms in adaptation of agriculture crops to abiotic stresses. World J. Microbiol. Biotechnol. 2011, 27, 1231-1240. [CrossRef]

146. Majeed, A.; Muhammad, Z.; Ahmad, H. Plant growth promoting bacteria: Role in soil improvement, abiotic and biotic stress management of crops. Plant Cell Rep. 2018, 37, 1599-1609. [CrossRef]

147. Islam, S. Microorganisms in the Rhizosphere and their Utilization in Agriculture: A Mini Review. PSM Microbiol. 2018, 3, 105-110. 
148. Shrivastava, P.; Kumar, R. Soil salinity: A serious environmental issue and plant growth promoting bacteria as one of the tools for its alleviation. Saudi J. Biol. Sci. 2015, 22, 123-131. [CrossRef] [PubMed]

149. Shahzad, R.; Khan, A.L.; Bilal, S.; Waqas, M.; Kang, S.M.; Lee, I.J. Inoculation ofabscisic acid-producing endophytic bacteria enhances salinity stress tolerance in Oryza sativa. Environ. Exp. Bot. 2017, 136, 68-77. [CrossRef]

150. Zhou, C.; Fi, L.; Xie, Y.; Zhu, L.; Xiao, X.; Ma, Z.; Wang, J. Involvement of abscisic acid in microbe-induced saline-alkaline resistance in plants. Plant Signal. Behav. 2017, 12, 1-4. [CrossRef] [PubMed]

151. Berendsen, R.L.; Vismans, G.; Yu, K.; Song, Y.; Jonge, R.; Burgman, W.P.; Pieterse, C.M. The disease-induced assemblage of a plant beneficial bacterial consortium. ISME J. 2018, 12, 1496-1507. [CrossRef] [PubMed]

152. Nadeem, S.M.; Ahmad, M.; Zahir, Z.A.; Javaid, A.; Ashraf, M. The role of mycorrhizae and plant growth promoting rhizobacteria (PGPR) in improving crop productivity under stressful environments. Biotechnol. Adv. 2014, 32, 429-448. [CrossRef] [PubMed]

153. Egamberdieva, D.; Davranov, K.; Wirth, S.; Hashem, A.; Abd Allah, E.F. Impact of soil salinity on the plant-growth-promoting and biological control abilities of root associated bacteria. Saudi J. Biol. Sci. 2017, 24, 1601-1608. [CrossRef]

154. Tewari, S.; Arora, N.K. Role of salicylic acid from Pseudomonas aeruginosa PF23EPS+ ingrowth promotion of sunflower in saline soils infested with phytopathogen Macrophomina phaseolina. Environ. Sustain. 2018, 1, 49-59. [CrossRef]

155. Pacwa-Płociniczak, M.; Płociniczak, T.; Iwan, J.; Żarska, M.; Chorażewski, M.; Dzida, M.; Piotrowska-Seget, Z Isolation of hydrocarbon-degrading and biosurfactant producing bacteria and assessment their plant growth-promoting traits. J. Environ. Manag. 2016, 168, 175-184. [CrossRef]

156. Mallick, I.; Bhattacharyya, C.; Mukherji, S.; Dey, D.; Sarkar, S.C.; Mukhopadhyay, U.K.; Ghosh, A. Effective rhizoinoculation and biofilm formation by arsenic immobilizing halophilic plant growth promoting bacteria (PGPB) isolated from mangrove rhizosphere: A step towards arsenic rhizoremediation. Sci. Total Environ. 2018, 610, 1239-1250. [CrossRef]

157. Kearl, J.; McNary, C.; Lowman, J.S.; Mei, C.; Aanderud, Z.T.; Smith, S.T.; West, J.; Colton, E.; Hamson, M.; Nielsen, B.L. Salt-tolerant halophyte rhizosphere bacteria stimulate growth of alfalfa in salty soil. Front. Microbiol. 2019, 10,1-11. [CrossRef]

158. Thavamani, P.; Samkumar, R.A.; Satheesh, V.; Subashchandrabose, S.R.; Ramadass, K.; Naidu, R.; Venkateswarlu, K.; Megharaj, M. Microbes from mined sites: Harnessing their potential for reclamation of derelict mine sites. Environ. Pollut. 2017, 230, 495-505. [CrossRef] [PubMed]

159. Jaemsaeng, R.; Jantasuriyarat, C.; Thamchaipenet, A. Molecular interaction of1-aminocyclopropane-1carboxylate deaminase (ACCD)-producing endophytic Streptomyces sp. GMKU 336 towards salt-stress resistance of Oryza sativa L. cv. KDML105. Sci. Rep. 2018, 8, 1-15. [CrossRef]

160. Hussein, K.A.; Joo, J.H. Plant growth-promoting rhizobacteria improved salinity tolerance of Lactuca sativa and Raphanus sativus. J. Microbiol. Biotechnol. 2018, 28, 938-945. [CrossRef] [PubMed]

161. Shilev, S.; Sancho, E.D.; Benlloch-Gonzalez, M. Rhizospheric bacteria alleviate salt-produced stress in sunflower. J. Environ. Manag. 2012, 95, S37-S41. [CrossRef] [PubMed]

162. Karlidag, H.; Esitken, A.; Yildirim, E.; Donmez, M.F.; Turan, M. Effects of plant growth promoting bacteria on yield, growth, leaf water content, membrane permeability, and ionic composition of strawberry under saline conditions. J. Plant Nutr. 2010, 34, 34-45. [CrossRef]

163. Singh, R.P.; Jha, P.N. Alleviation of salinity-induced damage on wheat plant by an ACC deaminase-producing halophilic bacterium Serratia sp. SL-12 isolated from a salt lake. Symbiosis 2016, 69, 101-111. [CrossRef]

164. Yasmeen, R.; Siddiqui, Z.S. Physiological responses of crop plants against Trichoderma harzianum in saline environment. Acta Bot. Croat. 2017, 76, 154-162. [CrossRef]

165. Omar, M.N.A.; Osman, M.E.H.; Kasim, W.A.; Abd El-Daim, I.A. Improvement of Salt Tolerance Mechanisms of Barley Cultivated Under Salt Stress Using Azospirillum brasilense. In Salinity and Water Stress: Improving Crop Efficiency; Ashraf, M., Ozturk, M., Athar, H., Eds.; Springer: Dordrecht, The Netherlands, 2009; Volume 44, pp. 133-147.

166. Kasim, W.A.; Gaafar, R.M.; Abou-Ali, R.M.; Omar, M.N.; Hewait, H.M. Effect of biofilm forming plant growth promoting rhizobacteria on salinity tolerance in barley. Ann. Agric. Sci. 2016, 61, 217-227. [CrossRef] 
167. Naz, I.; Bano, A.; Ul-Hassan, T. Isolation of phytohormones producing plant growth promoting rhizobacteria from weeds growing in Khewra salt range, Pakistan and their implication in providing salt tolerance to Glycine max L. Afr. J. Biotechnol. 2009, 8, 5762-5768. [CrossRef]

168. Bal, H.B.; Nayak, L.; Das, S.; Adhya, T.K. Isolation of ACC deaminase producing PGPR from rice rhizosphere and evaluating their plant growth promoting activity under salt stress. Plant Soil 2013, 366, 93-105. [CrossRef]

169. Sadiki, M.; Rabih, K. Selection of chickpea (Cicer arietinum) for yield and symbiotic nitrogen fixation ability under salt stress. Agronomie 2001, 21, 659-666. [CrossRef]

170. Jung, J.K.H.; McCouch, S. Getting to the roots of it: Genetic and hormonal control of root architecture. Front. Plant Sci. 2013, 4, 57-60. [CrossRef] [PubMed]

171. Georgiev, G.I.; Atkins, C.A. Effects of salinity on $\mathrm{N}_{2}$ fixation, nitrogen metabolism and export and diffusive conductance of cowpea root nodules. Symbiosis 1993, 15, 239-255.

172. Delgado, M.J.; Garrido, J.M.; Ligero, F.; Lluch, C. Nitrogen fixation and carbon metabolism by nodules and bacteroids of pea plants under sodium chloride. Physiol. Plant. 1993, 89, 824-829. [CrossRef]

173. Hanin, M.; Ebel, C.; Ngom, M.; Laplaze, L.; Masmoudi, K. New insights on plant salt tolerance mechanisms and their potential use for breeding. Front. Plant Sci. 2016, 7, 1-17. [CrossRef] [PubMed]

174. Bertrand, A.; Prévost, D.; Juge, C.; Chalifour, F.P. Impact of elevated $\mathrm{CO}_{2}$ on carbohydrate and ureide content in soybean inoculated with different strains of Bradyrhizobium japonicum. Botany 2011, 89, 481-490. [CrossRef]

175. Hafeez, F.Y.; Aslam, Z.; Malik, K.A. Effect of salinity and inoculation on growth, nitrogen fixation and nutrient uptake of Vigna radiata (L.) Wilczek. Plant Soil 1988, 106, 3-8. [CrossRef]

176. Woldeyohannes, W.H.; Dasilva, M.C.; Gueye, M. Nodulation and nitrogen fixation of Stylosanthes hamata in response to induced drought stress. Arid Land Res. Manag. 2007, 21, 157-163. [CrossRef]

177. Bala, N.; Sharma, P.K.; Lakshminarayana, K. Nodulation and nitrogen-fixation by salinity-tolerant rhizobia in symbiosis with tree legumes. Agric. Ecosyst. Environ. 1990, 33, 33-46. [CrossRef]

178. Rabie, G.H.; Aboul-Nasr, M.B.; Al-Humiany, A. Increased salinity tolerance of cowpea plants by dual inoculation of an arbuscular mycorrhizal fungus Glomus clarum and a nitrogen-fixer Azospirillum brasilense. Mycobiology 2005, 33, 51-60. [CrossRef]

179. Nogales, J.; Campos, R.; BenAbdelkhalek, H.; Olivares, J.; Lluch, C.; Sanjuan, J. Rhizobium tropici genes involved in free-living salt tolerance are required for the establishment of efficient nitrogen-fixing symbiosis with Phaseolus vulgaris. Mol. Plant-Microbe Interact. 2002, 15, 225-232. [CrossRef] [PubMed]

180. Huang, C.Y.; Roessner, U.; Eickmeier, I.; Genc, Y.; Callahan, D.L.; Shirley, N.; Langridge, P.; Bacic, A. Metabolite profiling reveals distinct changes in carbon and nitrogen metabolism in phosphate-deficient barley plants (Hordeum vulgare L.). Plant Cell Physiol. 2008, 49, 691-703. [CrossRef] [PubMed]

181. Pradhan, N.; Sukla, L.B. Solubilization of inorganic phosphates by fungi isolated from agriculture soil. Afr. J. Biotechnol. 2006, 5, 850-854.

182. Nautiyal, C.S. An efficient microbiological growth medium for screening phosphate-solubilizing microorganism. FEMS Microbiol. Lett. 1999, 170, 265-270. [CrossRef] [PubMed]

183. Zhu, D.; Ouyang, L.; Xu, Z.; Zhang, L. Rhizobacteria of Populus euphratica promoting plant growth against heavy metals. Int. J. Phytoremediat. 2015, 17, 973-980. [CrossRef]

184. Gupta, N.; Sahoo, D.; Basak, U.C. Evaluation of in vitro solubilization potential of phosphate solubilising Streptomyces isolated from phyllosphere of Heritiera fomes (mangrove). Afr. J. Microbiol. Res. 2010, 4, 136-142.

185. Rojas-Tapias, D.; Moreno-Galvan, A.; Pardo-Diaz, S.; Obando, M.; Rivera, D.; Bonilla, R. Effect of inoculation with plant growth-promoting bacteria (PGPB) on amelioration of saline stress in maize (Zea mays). Appl. Soil Ecol. 2012, 61, 264-272. [CrossRef]

186. Nautiyal, C.S.; Bhadauria, S.; Kumar, P.; Lal, H.; Mondal, R.; Verma, D. Stress induced phosphate solubilization in bacteria isolated from alkaline soils. FEMS Microbiol. Lett. 2000, 182, 291-296. [CrossRef]

187. Wei, Y.; Zhao, Y.; Shi, M.; Cao, Z.; Lu, Q.; Yang, T.; Fan, Y.; Wei, Z. Effect of organic acids production and bacterial community on the possible mechanism of phosphorus solubilization during composting with enriched phosphate-solubilizing bacteria inoculation. Bioresour. Technol. 2018, 247, 190-199. [CrossRef]

188. Zaidi, A.; Khan, M.; Ahemad, M.; Oves, M. Plant growth promotion by phosphate solubilizing bacteria. Acta Microbiol. Immunol. Hung. 2009, 56, 263-284. [CrossRef]

189. Mahajan, S.G.; Nandre, V.S.; Salunkhe, R.C.; Shouche, Y.S.; Kulkarni, M.V. Chemotaxis physiological adaptation of an indigenous abiotic stress tolerant plant growth promoting Pseudomonas stutzeri: Amelioration of salt stress to Cicer arietinum. Biocatal. Agric. Biotechnol. 2020, 27, 1-9. [CrossRef] 
190. Li, X.; Sun, P.; Zhang, Y.; Jin, C.; Guan, C. A novel PGPR strain Kocuria rhizophila Y1 enhances salt stress tolerance in maize by regulating phytohormone levels, nutrient acquisition, redox potential, ion homeostasis, photosynthetic capacity and stress-responsive genes expression. Environ. Exp. Bot. 2020, 174, 1-18. [CrossRef]

191. Shaterian, J.; Waterer, D.; De-Jong, H.; Tanino, K.K. Differential stress response to $\mathrm{NaCl}$ salt application in early and late maturing diploid potato (Solanum sp.) clones. Environ. Exp. Bot. 2005, 54, 202-212. [CrossRef]

192. Manai, J.; Gouia, H.; Corpas, F.J. Redox and nitric oxide homeostasis are affected in tomato (Solanum lycopersicum) roots under salinity-induced oxidative stress. J. Plant Physiol. 2014, 171, 1028-1035. [CrossRef] [PubMed]

193. Santner, A.; Estelle, M. Recent advances and emerging trends in plant hormone signaling. Nature 2009, 459, 1071-1078. [CrossRef]

194. Kazan, K. Diverse roles of jasmonates and ethylene in abiotic stress tolerance. Trends Plant Sci. 2015, 20, 219-229. [CrossRef]

195. Balloi, A.; Rolli, E.; Marasco, R. The role of microorganisms in bioremediation and phytoremediation of polluted and stressed soils. Agrochimica 2010, 54, 353-369.

196. Egamberdieva, D.; Jabborova, D.; Hashem, A. Pseudomonas induces salinity tolerance in cotton (Gossypium hirsutum) and resistance to Fusarium root rot through the modulation of indole-3-acetic acid. Saudi J. Biol. Sci. 2015, 22, 773-779. [CrossRef]

197. Pérez-Alfocea, F.; Albacete, A.; Ghanem, M.E.; Dodd, I.C. Hormonal regulation of source-sink relations to maintain crop productivity under salinity: A case study of root-to-shoot signaling in tomato. Funct. Plant Biol. 2010, 37, 592-603. [CrossRef]

198. Sharaf, E.F.; Farrag, A.A. Induced resistance in tomato plants by IAA against Fusarium oxysporum lycopersici. Pol. J. Microbiol. 2004, 53, 111-116.

199. Rupal, K.S.; Raval, V.H.; Saraf, M. Biosynthesis and purification of indole-3-acetic acid by halotolerant rhizobacteria isolated from Little Runn of Kachchh. Biocatal. Agric. Biotechnol. 2020, 23, 1-6. [CrossRef]

200. Ullah, I.; Khan, A.R.; Park, G.S.; Lim, J.H.; Waqas, M.; Lee, I.J.; Shin, J.H. Analysis of phytohormones and phosphate solubilization in Photorhabdus spp. Food Sci. Biotechnol. 2013, 22, 25-31. [CrossRef]

201. Gupta, G.; Parihar, S.S.; Ahirwar, N.K.; Snehi, S.K.; Singh, V. Plant growth promoting rhizobacteria (PGPR): Current and future prospects for development of sustainable agriculture. J. Microb. Biochem. Technol. 2015, 7, 96-102. [CrossRef]

202. Vives-Peris, V.; Gomez-Cadenas, A.; Perez-Clemente, R.M. Salt stress alleviation in citrus plants by plant growth-promoting rhizobacteria Pseudomonas putida and Novosphingobium sp. Plant Cell Rep. 2018, 37, 1557-1569. [CrossRef]

203. Ghanem, M.E.; Albacete, A.; Smigocki, A.C.; Frébort, I.; Pospíšilová, H.; Martínez-Andújar, C.; Acosta, M.; Sánchez-Bravo, J.; Lutts, S.; Dodd, I.C.; et al. Root-synthesised cytokinins improve shoot growth and fruit yield in salinised tomato (Solanum lycopersicum L.). J. Exp. Bot. 2011, 62, 125-140. [CrossRef] [PubMed]

204. Wáskiewicz, A.; Gładysz, O.; Goliñski, P. Participation of phytohormones in adaptation to salt stress. In Plant Hormones under Challenging Environmental Factors; Ahammed, G.J., Yu, J.Q., Eds.; Springer: Dordrecht, The Netherlands, 2016; pp. 75-115.

205. Albacete, A.; Ghanem, M.E.; Martinez-Andujar, C.; Acosta, M.; Sanchez-Bravo, J.; Martinez, V.; Lutts, S.; Dodd, I.C.; Perez-Alfocea, F. Hormonal changes in relation to biomass partitioning and shoot growth impairment in salinized tomato (Solanum lycopersicum L.) plants. J. Exp. Bot. 2008, 59, 4119-4131. [CrossRef]

206. Kumari, P.; Khanna, V. ACC-deaminase and EPS production by salt tolerant rhizobacteria augment growth in chickpea under salinity stress. Int. J. Bioresour. Stress Manag. 2015, 6, 558-565. [CrossRef]

207. Poli, A.; Anzelmo, G.; Nicolaus, B. Bacterial Exopolysaccharides from Extreme Marine Habitats: Production, Characterization and Biological Activities. Mar. Drugs 2010, 8, 1779-1802. [CrossRef]

208. Flemming, H.C.; Wingender, J. Relevance of microbial extracellular polymeric substances (EPSs)-parts I: Structural and ecological aspects. Water Sci. Technol. 2001, 43, 1-8. [CrossRef]

209. Ojuederie, O.B.; Babalola, O.O. Microbial and Plant-Assisted Bioremediation of Heavy Metal Polluted Environments: A Review. Int. J. Environ. Res. Public Health 2017, 14, 1504. [CrossRef]

210. Arora, M.; Kaushik, A.; Rani, N.; Kaushik, C.P. Effect of cyanobacterial exopolysaccharides on salt stress alleviation and seed germination. J. Environ. Biol. 2010, 31, 701-704.

211. Chan, R.; Lam, J.S.; Lam, K.; Costerton, J.W. Influence of culture conditions on expression of the mucoid mode of growth of Pseudomonas aeruginosa. J. Clin. Microbiol. 1984, 19, 8-16. [CrossRef] [PubMed] 
212. Ishii, S.; Koki, J.; Unno, H.; Hori, K. Two Morphological Types of Cell Appendages on a Strongly Adhesive Bacterium, Acinetobacter sp. Strain Tol 5. Appl. Environ. Microbiol. 2004, 70, 5026-5029. [CrossRef] [PubMed]

213. Qurashi, A.W.; Sabri, A.N. Bacterial exopolysaccharide and biofilm formation stimulate chickpea growth and soil aggregation under salt stress. Braz. J. Microbiol. 2012, 43, 1183-1191. [CrossRef] [PubMed]

214. Batool, R.; Hasnain, S. Growth stimulatory effects of Enterobacter and Serratia located from biofilms on plant growth and soil aggregation. Biotechnol 2005, 4, 347-353. [CrossRef]

215. Banerjee, A.; Sarkar, S.; Cuadros-Orellana, S.; Bandopadhyay, R. Exopolysaccharides and Biofilms in Mitigating Salinity Stress: The Biotechnological Potential of Halophilic and Soil-Inhabiting PGPR Microorganisms. In Microorganisms in Saline Environments: Strategies and Functions; Giri, B., Varma, A., Eds.; Springer: Cham, Switzerland, 2019; pp. 303-330.

216. Fathalla, M.A. Effectiveness of exopolysaccharides and biofilm forming plant growth promoting rhizobacteria on salinity tolerance of faba bean (Vicia faba L.). Afr. J. Microbiol. Res. 2018, 12, 399-404. [CrossRef]

217. Grattan, S.R.; Grieve, C.M. Salinity-mineral nutrient relations in horticultural crops. Sci. Hortic. 1999, 78, 127-157. [CrossRef]

218. Ahmad, M.T.; Asghar, H.N.; Saleem, M.; Khan, M.Y.; Zahir, Z.A. Synergistic effect of rhizobia and biochar on growth and physiology of maize. Agron. J. 2015, 107, 2327-2334. [CrossRef]

219. Etesami, H.; Mirseyed Hosseini, H.; Alikhani, H.A. In planta selection of plant growth promoting endophytic bacteria for rice (Oryza sativa L.). J. Soil Sci. Plant Nutr. 2014, 14, 491-503. [CrossRef]

220. Mukherjee, A.; Gaurav, A.K.; Singh, S.; Chouhan, G.K.; Kumar, A.; Das, S. Role of Potassium (K) Solubilizing Microbes (KSM) in growth and induction of resistance against biotic and abiotic stress in plant: A book review. Clim. Chang. Environ. Sustain. 2019, 7, 212-214.

221. Vejan, P.; Abdullah, R.; Khadiran, T.; Ismail, S. Role of plant growth promoting rhizobacteria in agricultural sustainability-A review. Molecules 2016, 21, 573. [CrossRef] [PubMed]

222. Han, H.S.; Lee, K.D. Plant growth-promoting rhizobacteria: Effect on antioxidant status, photosynthesis, mineral uptake and growth of lettuce under soil salinity. Res. J. Agric. Biol. Sci. 2005, 1, 210-215.

223. Glick, B.R.; Cheng, Z.; Czarny, J.; Duan, J. Promotion of plant growth by ACC deaminase producing soil bacteria. Eur. J. Plant Pathol. 2007, 119, 329-339. [CrossRef]

224. Adesemoye, A.O.; Egamberdieva, D. Beneficial Effects of Plant Growth-Promoting Rhizobacteria on Improved Crop Production: Prospects for Developing Economies. In Bacteria in Agrobiology: Crop Productivity; Maheshwari, D.K., Saraf, M., Aeron, A., Eds.; Springer: Berlin/Heidelberg, Germany, 2013; pp. 45-63.

225. Timmusk, S. Mechanism of action of the plant growth promoting Bacterium Paenibacillus polymyxa. In The Comprehensive Summaries of Uppsala Dissertations from the Faculty of Science and Technology 908; Acta Universitatis Upsaliensis: Uppsala, Sweden, 2003; p. 40.

226. Völker, U.; Engelmann, S.; Maul, B.; Riethdorf, S.; Völker, A.; Schmid, R.; Mach, H.; Hecker, M. Analysis of the induction of general stress proteins of Bacillus subtilis. Microbiology 1994, 140, 741-752. [CrossRef] [PubMed]

227. Rajendrakumar, C.S.V.; Suryanarayana, T.; Reddy, A.R. DNA helix destabilization by proline and betaine: Possible role in the salinity tolerance process. FEBS Lett. 1997, 410, 201-205. [CrossRef]

228. Potts, M. Desiccation tolerance of prokaryotes. Microbiol. Rev. 1994, 58, 755-805. [CrossRef]

229. Breedveld, M.W.; Dijkema, C.; Zevenhuizen, L.; Zehnder, A.J.B. Response of intracellular carbohydrates to a $\mathrm{NaCl}$ shock in Rhizobium leguminosarum biovar trifolii TA1 and Rhizobium meliloti SU47. J. Gen. Microbiol. 1993, 139, 3157-3163. [CrossRef]

230. Gouffi, K.; Pica, N.; Pichereau, V.; Blanco, B. Disaccharides as a new class of non-accumulated osmoprotectants for Sinorhizobium meliloti. Appl. Environ. Microbiol. 1999, 65, 1491-1500. [CrossRef]

231. Flowers, T.J.; Troke, P.F.; Yeo, A.R. The mechanism of salt tolerance in halophytes. Annu. Rev. Plant Physiol. 1977, 28, 89-121. [CrossRef]

232. Das, P.; Behera, B.K.; Meena, D.K.; Azmi, S.A.; Chatterjee, S.; Meena, K.; Sharma, A.P. Salt stress tolerant genes in halophilic and halotolerant bacteria: Paradigm for salt stress adaptation and osmoprotection. Int. J. Curr. Microbiol. Appl. Sci. 2015, 4, 642-658.

233. Singh, R.P.; Jha, P.N. The multifarious PGPR Serratia marcescens CDP-13 augments induced systemic resistance and enhanced salinity tolerance of wheat (Triticum aestivum L.). PLoS ONE 2016, 11, e0155026. [CrossRef] [PubMed]

234. Bartels, D.; Sunkar, R. Drought and salt tolerance in plants. Crit. Rev. Plant Sci. 2005, 24, 23-58. [CrossRef] 
235. Zafar-ul-Hye, M.; Farooq, H.M.; Hussain, M. Bacteria in combination with fertilizers promote root and shoot growth of maize in saline-sodic soil. Braz. J. Microbiol. 2015, 46, 97-102. [CrossRef] [PubMed]

236. Penrose, D.; Glick, B. Methods for isolating and characterizing ACC deaminase-containing plant growth-promoting rhizobacteria. Physiol. Plant. 2003, 118, 10-15. [CrossRef] [PubMed]

237. Ahmad, M.; Zahir, Z.A.; Asghar, H.N.; Asghar, M. Inducing salt tolerance in mung bean through coinoculation with rhizobia and plant growth-promoting rhizobacteria containing 1-aminocyclopropane-1-carboxylate deaminase. Can. J. Microbiol. 2011, 57, 578-589. [CrossRef] [PubMed]

238. Sepúlveda-Caamaño, M.; Gerding, M.; Vargas, M.; Moya-Elizondo, E.; Oyarzúa, P.; Campos, J. Lentil (Lens culinaris L.) growth promoting rhizobacteria and their effect on nodulation in coinoculation with rhizobia. Arch. Agron. Soil Sci. 2018, 64, 244-256. [CrossRef]

239. Del Carmen Orozco-Mosqueda, M.; Glick, B.R.; Santoyo, G. ACC deaminase in plant growth-promoting bacteria (PGPB): An efficient mechanism to counter salt stress in crops. Microbiol. Res. 2020, 235, 1-10. [CrossRef]

240. Dobbelaere, S.; Vanderleyden, J.; Okon, Y. Plant growth promoting effects of diazotrophs in the rhizosphere. Crit. Rev. Plant Sci. 2003, 22, 107-149. [CrossRef]

241. Li, J.; Ovakim, D.H.; Charles, T.C.; Glick, B.R. An ACC deaminase minus mutant of Enterobacter cloacae UW4No longer promotes root elongation. Curr. Microbiol. 2000, 41, 101-105. [CrossRef]

242. Cheng, Z.; Park, E.; Glick, B.R. 1-Aminocyclopropane-1-carboxylate deaminase from Pseudomonas putida UW4 facilitates the growth of canola in the presence of salt. Can. J. Microbiol. 2007, 53, 912-918. [CrossRef]

243. Tiwari, G.; Duraivadivel, P.; Sharma, S.; Hariprasad, P. 1- Aminocyclopropane-1-carboxylic acid deaminase producing beneficial rhizobacteria ameliorate the biomass characters of Panicum maximum Jacq. by mitigating drought and salt stress. Sci. Rep. 2018, 8, 1-12. [CrossRef] [PubMed]

244. Kausar, R.; Shahzad, S. Effect of ACC-deaminase containing rhizobacteria on growth promotion of maize under salinity stress. J. Agric. Soc. Sci. 2006, 2, 216-218.

245. Yang, J.; Kloepper, J.W.; Ryu, C.M. Rhizosphere bacteria help plants tolerate abiotic stress. Trends Plant Sci. 2010, 14, 1-4. [CrossRef] [PubMed]

246. Madhaiyan, M.; Poonguzhali, S.; Sa, T.M. Characterization of 1-Aminocyclopropane-1-carboxylate deaminase ACC deaminase containing Methylobacterium oryzae and interactions with auxins and ACC regulation of ethylene in canola (Brassica campestris). Planta 2007, 226, 867-876. [CrossRef]

247. Shaharoona, B.; Arshad, M.; Zahir, Z.A. Effect of plant growth promoting rhizobacteria containing ACC-deaminase on maize (Zea mays L.) growth under axenic conditions and on nodulation in mung bean (Vigna radiata L.). Lett. Appl. Microbiol. 2006, 42, 155-159. [CrossRef]

248. Shrivasta, U.P.; Kumar, A. Characterization and optimization of 1-aminocyclopropane-1-carboxylate deaminase (ACCD activity in different rhizospheric PGPR along with Microbacterium sp. strain ECI-12A. Int. J. Appl. Sci. Biotechnol. 2014, 1, 11-15. [CrossRef]

249. Van Loon, L.C.; Bakker, P.A.; Pieterse, C.M. Systemic resistance induced by rhizosphere bacteria. Annu. Rev. Phytopathol. 1998, 361, 453-483. [CrossRef]

250. Barriuso, J.; Solano, B.R.; Gutiérrez Mañero, F.J. Protection against pathogen and salt stress by four plant growth-promoting rhizobacteria isolated from Pinus sp. on Arabidopsis thaliana. Phytopathology 2008, 98, 666-672. [CrossRef]

251. Olanrewaju, O.S.; Glick, B.R.; Babalola, O.O. Mechanisms of action of plant growth promoting bacteria. World J. Microbiol. Biotechnol. 2017, 33, 1-16. [CrossRef]

252. Singh, R.P.; Jha, P.N. The PGPR Stenotrophomonas maltophilia SBP-9 augments resistance against biotic and abiotic stress in wheat plants. Front. Microbiol. 2017, 8, 1-15. [CrossRef]

253. Morgan, P.W.; Drew, M.C. Ethylene and plant responses to stress. Physiol. Plant. 1997, 100, 620-630. [CrossRef]

254. Abeles, F.B.; Morgan, P.W.; Saltveit, M.E., Jr. Ethylene in Plant Biology, 2nd ed.; Academic Press: San Diego, CA, USA, 1992; pp. 56-176.

255. Selvakumar, G.; Panneerselvam, P.; Ganeshamurthy, A.N. Bacterial mediated alleviation of abiotic stress in crops. In Bacteria in Agrobiology: Stress Management; Maheshwari, D.K., Ed.; Springer: Berlin/Heidelberg, Germany, 2012; pp. 205-224.

256. Sharma, A.; Vaishnav, A.; Jamali, H.; Srivastava, A.K.; Saxena, A.K.; Srivastava, A.K. Halophilic bacteria: Potential bioinoculants for sustainable agriculture and environment management under salt stress. In Plant-Microbe Interaction: An Approach to Sustainable Agriculture; Choudhary, D., Varma, A., Tuteja, N., Eds.; Springer: Singapore, 2016; pp. 297-325. 
257. Hussain, S.; Huang, J.; Zhu, C.; Zhu, L.; Cao, X.; Hussain, S.; Ashraf, M.; Khaskheli, M.A.; Kong, Y.; Jin, Q.; et al. Pyridoxal 5'-phosphate enhances the growth and morpho-physiological characteristics of rice cultivars by mitigating the ethylene accumulation under salinity stress. Plant Physiol. Biochem. 2020, 154, 782-795. [CrossRef] [PubMed]

258. Misra, S.; Chauhan, P.S. ACC deaminase-producing rhizosphere competent Bacillus spp. mitigate salt stress and promote Zea mays growth by modulating ethylene metabolism. 3 Biotech 2020, 10, 1-14. [CrossRef] [PubMed]

259. Gamalero, E.; Glick, B.R. Bacterial modulation of plant ethylene levels. Plant Physiol. 2015, 169, $13-22$. [CrossRef] [PubMed]

260. Timmusk, S.; Behers, L.; Muthoni, J.; Muraya, A.; Aronsson, A.C. Perspectives and challenges of microbial application for crop improvement. Front. Plant Sci. 2017, 8, 1-10. [CrossRef] [PubMed]

261. Yadav, A.N. Beneficial role of extremophilic microbes for plant health and soil fertility. J. Agric. Sci. Bot. 2017, 1, 30-33. [CrossRef]

262. Akhtar, S.S.; Andersen, M.N.; Liu, F. Biochar mitigates salinity stress in potato. J. Agron. Crop Sci. 2015, 201, 368-378. [CrossRef]

263. Amacher, J.K.; Koenig, K.; Kitchen, B. Salinity and Plant Tolerance. Available online: https://extension.usu. edu/files/publications/publication/AG-SO-03.pdf (accessed on 30 April 2020).

264. Arora, N.K.; Tewari, S.; Singh, S.; Lal, N.; Maheshwari, D.K. PGPR for protection of plant health under saline conditions. In Bacteria in Agrobiology: Stress Management; Maheshwari, D., Ed.; Springer: Berlin/Heidelberg, Germany, 2012; pp. 239-258.

(C) 2020 by the authors. Licensee MDPI, Basel, Switzerland. This article is an open access article distributed under the terms and conditions of the Creative Commons Attribution (CC BY) license (http://creativecommons.org/licenses/by/4.0/). 